Studia Theologica Varsaviensia UKSW

$2 / 2020$

MAREK ŁAGOSZ

\title{
WOLNOŚĆ CZŁOWIEKA W PERSPEKTYWIE TEOLOGICZNEJ ORAZ W TEOLOGII FILOZOFICZNEJ (GEORG W.F. HEGEL, FRIEDRICH W. J SCHELLING)
}

\section{WSTĘP}

Wolność człowieka w materialnym świecie stanowi jedną z największych zagadek filozoficznych (ontologicznych). Jak to możliwe, że pojawia się ona w rzeczywistości, którą rządzi determinizm? Przy czym obojętne jest, czy myślimy tu o determinizmie jednoznacznym czy statystycznym (indeterminizm standardowej /kopenhaskiej/ interpretacji mechaniki kwantowej) - oba równie mało nadają się do uzasadnienia ludzkiej wolności. I chociaż wolność człowieka można kwestionować na zasadzie: myśla, że moga, gdyż nie wiedza, że musza, to jej uznanie stanowi tak fundamentalne podwaliny życia ludzkiego (moralności indywidualnej i społecznej odpowiedzialności), że doprawdy trudno się bez niego obyć.

Ponieważ zaś w kontekście sporu kompatybilistów z inkompatybilistami w filozofii wolności, skłaniam się ku stanowisku tych ostatnich, tj. przyjmuję hipotezę (którą w artykule staram się też uzasadnić), że determinizmu rządzącego materialnym wszechświatem nie da się pogodzić z istnieniem w nim wolności ludzkiej, tę ostatnią rozważam w perspektywie teologicznej. Przy czym uwzględniam nie tylko klasyczną myśl teologiczną, lecz także teologię filozoficzną 


\section{HUMAN FREEDOM \\ IN THEOLOGICAL PERSPECTIVE AND IN PHILOSOPHICAL THEOLOGY (GEORG W.F. HEGEL, FRIEDRICH W. J SCHELLING)}

\section{INTRODUCTION}

Human freedom in the material world is one of the greatest philosophical (ontological) puzzles. How is it possible that it appears in a reality governed by determinism? Whether we think of unambiguous determinism or statistical determinism (the indeterminism of the standard /Copenhagen/ interpretation of quantum mechanics) is irrelevant here as they are both equally inadequate to justify human freedom. And although human freedom can be questioned in terms of they think they can, because they do not know they must, its recognition is actually so fundamental to human life (individual morality and social responsibility) that it is truly difficult to do without it.

Since, in the context of the dispute between compatibilists and incompatibilists in the philosophy of freedom, the author of the paper favours the view of the latter, i.e. adopts the hypothesis (which he tries to prove in the paper) that the determinism governing the material universe cannot be reconciled with the existence of human freedom in it, it is the latter that he discusses from a theological perspective. However, not only does the author consider classical theological 
Friedricha W.J. Schellinga oraz Georga W.F. Hegla. Spodziewam się, że taki właśnie punkt widzenia dobrze wytłumaczy obecność wolności w deterministycznym świecie oraz pozwoli określić jej prawdziwą naturę, tj. odpowie na pytanie: na czym tak naprawdę polega najwyższy stopień ludzkiej wolności.

\section{WOLNOŚĆ JAKO „OBRAZ I PODOBIEŃSTWO” BOGA. RÓŻNE STOPNIE WOLNOŚCI}

Jedną z możliwych, a zarazem fundamentalnych odpowiedzi na pytanie: co upodabnia istnienie człowieka do Boga?, jest wskazanie na wolność.

Friedrich Wilhelm Joseph Schelling ujmuje to tak: „Wychodzenie rzeczy z Boga jest Bożym samoobjawieniem. Bóg jednak może się objawić tylko w tym, co jest mu podobne, w wolnych, działających z samych siebie istotach; dla ich bytu nie ma innej podstawy niż Bóg, istnieją jednak tak, jak on istnieje" . Hans Urs von Balthasar pisze zaś: ,[...] tak samo wolność skończona (wolność właściwa człowiekowi - M. Ł.) - jako czysty dynamizm wywodzący się z Wolności Nieskończonej i do niej powracający - jest najbardziej odpowiadającym obrazem Boga"'2.

Chociaż wszystkie przedmioty istniejące są zależne od Boga (są - jako określone-stworzone i podtrzymywane przez niego w istnieniu), to Bóg udzielił im w różnym stopniu wolności. I tak materia nieożywiona oraz ożywiona „szczebla podludzkiego" posiada wolność w stopniu minimalnym - jest to wolność „ślepa”, polegająca na przypadkowości „,kwantowych przeskoków” lub na modyfikowaniu działania instynktów wpływami środowiska. Taka statystyczna

1 F.W. J. Schelling, Filozoficzne badania nad istota wolności i sprawami z tym zwiąanymi, inter esse, Kraków 1990, s. 45.

2 H.U. von Balthasar, Teodramatyka 2. Osoby dramatu, cz. 1. Człowiek w Bogu, Wydawnictwo M, Kraków 2006, s. 223. [W innym miejscu zaś „,[..] ta wolność stworzenia stanowi podstawę nazwania go 'obrazem i podobieństwem Boga', ona jest też konkretnym wyrazem analogia entis [...]” (tamże, s. 113).] 
thought, but also the philosophical theology of Friedrich W.J. Schelling and Georg W.F. Hegel. This perspective is expected to explain well the presence of freedom in a deterministic world and to determine its true nature, i.e. to answer the question of what the highest degree of human freedom really consists in.

\section{FREEDOM AS THE GOD'S IMAGE AND LIKENESS. DIFFERENT DEGREES OF FREEDOM}

One possible and fundamental answer to the question what makes human existence resemble God is to point to freedom.

Friedrich Wilhelm Joseph Schelling puts it this way: "The procession [Folge] of things from God is a self-revelation of God. But God can only reveal himself to himself in what is like him, in free beings acting on their own, for whose Being there is no ground other than God but who are as God is." Hans Urs von Balthasar sees "[...] finite freedom (which, according to the author of the paper, means freedom inherent in man) - as a pure motion coming from and proceeding toward Infinite Freedom - is the closest image of God."

Although all existing objects are dependent on God (they are - as determined - created and sustained in existence by him), it is God who gave them freedom to various degrees. Thus inanimate matter and animate matter of the "subhuman level" possess freedom to a minimal degree - it is 'blind' freedom, consisting in the randomness of quantum leaps or in modifying the action of instincts by environmental influences. Such statistical potentiality, however, is not freedom 'for

1 F.W. J. Schelling, Philosophical Investigations into the Essence of Human Freedom, F.W. J. SCHELLING Translated and with an Introduction by Jeff Love and Johannes Schmidt, State University of New York, (2006) p. 18.

2 H.U. von Balthasar, Theo-Drama: Theological Dramatic Theory: The Dramatis Personae: Man in God, vol. 2, Ignatius Press. The Polish version has slightly modified according to the German original.

[ And elsewhere, ,[...] this freedom of the creature is the basis for calling it God's image and likeness, it is also the concrete analogia entis [...]" (ibid., p. 113).] 
potencjalność nie jest jednak wolnością „dla siebie” - wolnością wyboru, która zaczyna się wraz z człowiekiem³ ${ }^{3}$ Ogólnie chodzi o wolność do kształtowania swojego losu. Zwierzęta losu nie mają, gdyż nie posiadają dostatecznego stopnia wolności.

Warto przy tym zwrócić uwagę na ontologiczny związek wolności występującej w materialnym wszechświecie z tym, iż ten ostatni jest stworzony przez Boga. Otóż - jak zauważa Romano Guardini - we wszechświecie rozumianym jako istniejący odwiecznie - nie byłoby miejsca na wolność. „Dlatego też nowożytne pojęcie natury, które zaprzeczyło pojęciu świata jako faktu uczynionego przez Stwórcę, konsekwentnie musiało też zaprzeczyć pojęciu wolności: jeżeli świat jako całość musi być, wówczas także musi być to wszystko, co w nim jest" ". Krótko mówiąc: w odwiecznym świecie wszystko musi być konieczne. Tylko dzięki wolnemu aktowi twórczemu Boga i na jego mocy w świecie może ,zamieszkać” wolność.

Zdaje się, że w takim postawieniu sprawy jest sporo słuszności. Odwieczny świat materii, który rządzi się deterministyczną (jednoznacznie lub statystycznie) przyczynowością, nie ma w sobie żadnej zasady, która mogłaby wygenerować wolne podmioty. Ewolucyjnie wytwarza wprawdzie człowieka, lecz ten - analizowany w kategoriach fizyko-chemiczno-fizjologicznych jest tylko wysoce skomplikowanym mechanizmem (co skazuje nas na egzystencjalny bezsens), a na ogół wierzymy przecież, że jesteśmy czymś więcej: podmiotami wolnymi i odpowiedzialnymi.

$\mathrm{Z}$ drugiej jednak strony - na co zwraca uwagę Balthasar ${ }^{5}$ - pojęcie wolności stworzonej zdaje się wewnętrznie sprzeczne: czy ktoś, kto jest ograniczony u samych podstaw swego bytowania (od kogo nie zależy jego istnienie), może być istotą wolną? Zgodnie z założeniami teologii chrześcijańskiej może; Bóg udziela bytowi stworzonemu

${ }^{3} \mathrm{Z}$ zastrzeżeniem, że pewne rudymentarne jej formy mogą być właściwe niektórym zwierzętom.

${ }^{4}$ R. Guardini, Wolność-łaska-los. Rozważania o sensie istnienia, Wydawnictwo Znak, Kraków 1995, s. s. 181.

5 H.U. von Balthasar, Teodramatyka 2., cz. 1., s. 195. 
oneself' - freedom of choice, which begins with the human being ${ }^{3}$. It is generally about the freedom to shape one's own destiny. Animals do not have a destiny because they do not have a sufficient degree of freedom.

It is worth noting here the ontological connection between the freedom present in the material universe and the fact that the latter is created by God. As Romano Guardini observes, in a universe understood as existing eternally, there would be no room for freedom. "Therefore, the modern concept of nature, which denied the notion of the world as a fact made by the Creator, consequently also rejected the notion of freedom: if the world as a whole must exist, then all that is in it must also exist." ${ }^{\prime \prime}$ In brief, everything must be essential in an eternal world. Only by and through the free creative act of God can freedom "dwell" in the world.

There seems to be a good deal of validity in such an approach. The eternal world of matter, which is governed by deterministic (explicitly or statistically) causality, has no principle in itself that could generate free entities. Evolutionarily, it does create man, but this man - analysed in physical, chemical and physiological terms - is only a highly complicated mechanism ( what condemns us to existential futility), while we generally believe that we are something more than that: free and responsible individuals.

On the other hand, as Balthasar points out, ${ }^{5}$ the notion of created freedom seems contradictory: can someone who is limited at the very foundation of his being (on whom his existence does not depend) be a free being? According to Christian theology, he can; God grants freedom to the created being, but this freedom is always limited,

${ }^{3}$ Provided that certain rudimentary forms of it may be peculiar to certain animals.

${ }^{4}$ R. Guardini, Freedom, Grace, and Destiny: Three Chapters in the Interpretation of Existence, Pantheon Books, 1961; Polish edition by Znak Publishing House, Krakow 1995, p. 181.

${ }^{5}$ H.U. von Balthasar, Theo-Drama 2, vol. 1, p. 195. The Polish version has slightly modified according to the German original. 
wolności - tyle tylko że jest to wolność zawsze ograniczona, co oznacza - jak ujmuje to Balthasar - że ,[...] będąc wolni, jesteśmy zarazem zawsze dopiero w drodze do naszej wolności”'

Inna sprawa, że - ogólnie biorąc - nie ma logicznego związku między samą koniecznością istnienia czegoś, a niemożliwością immanentnej wolności tego czegoś. Bóg np. istnieje koniecznie, a jest - jak zakładamy - wolny w stopniu najwyższym. Podobnie też brak logicznego związku między byciem stworzonym, a zawieraniem w sobie pewnej dozy wolności: Bóg mógł przecież stworzyć świat ściśle i zupełnie deterministyczny - choć wierzymy, że tego nie zrobił. Tak więc argumentacja Guardiniego nie tyle ma siłę logiczną, co wyraża naszą rzeczywistą trudność w zrozumieniu, jak w deterministycznym świecie materii mogą istnieć wolne podmioty.

\section{HETERONOMICZNOŚĆ WOLNOŚCI}

Większość ludzi ma zasadnicze poczucie wolności własnych wyborów i czynów, mimo iż jesteśmy zanurzeni w przyrodzie, którą jak pokazuje to wiedza naukowa - rządzi przyczynowa konieczność (determinizm jednoznaczny) lub ,ślepa” statystyczność (determinizm statystyczny). Trudno tu podejmować w całej rozciągłości wątki wielowiekowych rozważań myślicieli nad pochodzeniem i naturą ludzkiej wolności. Chcę jedynie postawić hipotezę, że jest wysoce prawdopodobne, iż wolność, co do której zakładamy, że jest podstawą odpowiedzialnego ludzkiego działania, „nie z tego świata pochodzi”. Rozumiem przez to, że - opierając się na rozpoznaniu przyrody i prawidłowości deterministycznych (obojętnie: jednoznacznych czy statystycznych) - nie jesteśmy w stanie uzasadnić takiej wolności. Człowiek jako część przyrody podlega jej prawidłowościom, dlatego wszelkie tłumaczenie ludzkiej świadomości opierające się na naturze nie jest w stanie rozpoznać wolności. Co więcej zupełną rację ma Karl Rahner, kiedy twierdzi, że im bardziej psychologia jest radykalna w swej empiryczności, tym mniejszy zakres wolności odkrywa. Jest

\footnotetext{
6 Tamże.
} 
which means - as Balthasar puts it - that "[...] being free, we are at the same time always only on the way to our freedom."

On another note, there is generally no logical connection between the mere necessity of the existence of something and the impossibility of its immanent freedom. God, for example, exists necessarily, and is - as we assume - free in the highest degree. Similarly, there is no logical connection between being created and containing a certain amount of freedom: God could, after all, have created a strictly and completely deterministic world, though we believe he did not. So Guardini's argument does not so much have logical force as it expresses our real difficulty in understanding how free entities can exist in a deterministic world of matter.

\section{HETERONOMY OF FREEDOM}

Most people have a fundamental sense of the freedom of their own choices and actions, even though we are immersed in nature, which, as demonstrated by scientific knowledge, is governed by causal necessity (unambiguous determinism) or "blind" statisticality (statistical determinism). It is difficult here to take up in full the threads of centuries of thinkers' reflections on the origin and nature of human freedom. What the author seeks to do is to hypothesise that it is highly probable that the freedom we assume to be the basis of responsible human action "does not come from this world". And by that he means that, relying on a recognition of nature and deterministic regularities (whether unambiguous or statistical), we are unable to justify such freedom. Man, as part of nature, is subject to its regularities, and therefore any explanation of human consciousness based on nature fails to recognise freedom. Moreover, Karl Rahner is absolutely right when he claims that the more radical psychology is in its empiricism, the less freedom it discovers. Rahner's view is logical, for "an empirical psychology must reduce a given phenomenon to another phenomenon (as its cause, its determinant - explains the author of the paper), and in

\footnotetext{
6 Ibid.
} 
to zdaniem teologa logiczne, gdyż „psychologia empiryczna musi sprowadzać dane zjawisko do innego zjawiska (jako swojej przyczyny, determinanty - M.Ł.) i na tej drodze nie może oczywiście odkryć żadnej wolności”7. Inaczej mówiąc wolność i odpowiedzialność człowieka nie są danymi empirycznymi. Nie w takim jednak sensie, że nie przejawiają się w świecie, gdyż zakładamy przecież, że wolne czyny ludzkie mają miejsce w empirycznej rzeczywistości (dlatego np. karzemy przestępców), lecz w takim - że nie są one skutkami określonych zdarzeń naturalnych. Decyzja, którą określalibyśmy jako wolną, a zarazem wskazywali tylko na jej empiryczne determinanty, automatycznie traci przymiot wolności.

Przy czym fakt, że akty naszej woli oraz wypływające z nich czyny źródłowo nie są zdeterminowane empirycznie (przyrodniczo) nie oznacza, iż w ogóle nie są uwarunkowane. Jak zauważa Guardini: „Każdy wolny czyn rzeczywiście ma swoje motywy, każdy spełnia się 'z takiego czy innego powodu' ". . Motywacja istotnie jest przyczyną (może lepiej byłoby powiedzieć: racją) wolnego czynu. Jeśli chodzi o nasze działania, to mamy do czynienia z całymi ciągami motywacyjnymi - na wzór łańcuchów kauzalnych rządzących światem przyrody. Teolog zakłada jednak - że w przeciwieństwie do przyczynowości kauzalnej - przyczynowość motywacyjna nie jest przymusowa, a na końcu każdego z takich ciągów motywacyjnych jest wolna decyzja (,pierwotne zapoczątkowanie”9): „bo tak chcę"10. Wprawdzie można podważać taką interpretację, wskazując, że kolejne motywy czynów i zachowań są determinowane przyczynowo „oddolnie” (neurofizjologicznie) i mają przymusowy charakter; samo zaś pozornie wolne „bo tak chcę” uwarunkowane jest przez podstawowe popędy czy instynkty naturalne. Radykalni redukcjoniści

7 K. Rahner, Podstawowy wykład wiary. Wprowadzenie do pojęcia chrześcijaństwa, tłum. Tadeusz Mieszkowski, Instytut Wydawniczy PAX, Warszawa 1987, s. 35.

8 R. Guardini, Wolność-łaska-los, s. 102.

9 Tamże, s. 104

10 Tamże, s. 102. 
that way it cannot of course discover any freedom."7 In other words, human freedom and responsibility are not empirical data. Not in the sense that they do not manifest themselves in the world, for we assume that free human acts take place in empirical reality (which is why, for example, criminals are punished), but in the sense that they are not the effects of specific natural events. A decision that we would define as free, while pointing only to its empirical determinants, automatically loses the attribute of freedom.

However, the fact that the acts of our will and the actions that flow from them are not empirically (naturally) determined does not mean that they are not conditioned at all. As Guardini notes "every free act indeed has its motives, each one fulfils itself 'for one reason or another"." ${ }^{8}$ Motivation is indeed the cause (perhaps it would be better to say the rationale) of a free act. When it comes to our actions, we are faced with entire motivational sequences - like the causal chains that govern the natural world. However, the theologian assumes that, unlike causal causality, motivational causality is not coercive, and that there is a free decision ("original initiation"), i.e. 'because I want to. ${ }^{10}$ Admittedly, one may question such an interpretation, pointing out that subsequent motives of actions and behaviours are causally determined " bottom-up" (neurophysiologically) and have a compulsory character; while the seemingly free "because I want to" itself is conditioned by basic drives or natural instincts. In fact, it is this path that the radical reductionists follow, rejecting the reality of "free initiative". For Guardini, however, what unfailingly ("absolutely") attests to the reality of the latter is our awareness of responsibility. Needless to say, reductionists will refute this argument as well, pointing out that the very sense of responsibility can be (or even is)

7 K. Rahner, The Fundations of Christian Faith: An Introduction to the Idea of Christianity, transl. Tadeusz Mieszkowski, Instytut Wydawniczy PAX, Warsaw 1987 , p. 35.

8 R. Guardini, Freedom, Grace, and Destiny, p. 102.

9 Ibid, p. 104

${ }^{10}$ Ibid, p. 102. 
idą właśnie tą drogą, odrzucając realność ,wolnej inicjatywy”. Dla Guardiniego jednak tym, co niezawodnie (,bezwzględnie”) świadczy o realności tej ostatniej jest nasza świadomość odpowiedzialności. Nie trzeba dodawać, że redukcjoniści będą uchylali i ten argument, wskazując, że samo poczucie odpowiedzialności może być (czy też jest) złudne - na zasadzie: myślimy, że za cokolwiek odpowiadamy, gdyż nie zdajemy sobie sprawy, że wszystko, cokolwiek uczyniliśmy, uczynić musieliśmy.

Skoro mówimy o motywacjach i wieńczących je aktach wolnych decyzji, to zauważmy jeszcze, że motywacji dla ludzkich czynów zawsze powinien dostarczać także (obok pożądania, upodobania etc.) rozum - instancja pozwalająca rozpoznać dobro i zło w sensie moralnym. Jak słusznie bowiem zauważa Balthasar: „Jeżeli wolność sytuuje się jednostronnie w rozumie (Stoa), albo w samej woli (Szkot, tendencja Descartesa, Rousseaux i in.), wtedy zawsze schodzi się poniżej człowieczeństwa, na poziom instynktu" "11. Instynkt (pożądanie) nie musi rozumieć swego chcenia, jednakże moralność domaga się rozpoznania tego, co dobre, a co złe. Samo jednak czysto racjonalne rozpoznanie jeszcze nie wystarcza, jeśli chodzi o cnotę - dobra (wbrew intelektualizmowi etycznemu) trzeba jeszcze chcieć. Chociaż nie jest calkiem wykluczone, że najwyższą wolność daje poznanie Dobra samego, gdyż wtedy chce się już tylko jego.

Skoro wolność nie mieści się $\mathrm{w}$ deterministycznym porządku przyrody, to może racje mają transcendentaliści, przeciwstawiający w człowieku transcendentalną sferę praktyczności, w której „,rządzi” wolność, empirycznej sferze natury. Skąd jednak - można by się dopytywać - ten „rozłam w naturze człowieka”, ta niejednolitość wolności i przyczynowości? Synchronicznie biorąc, byłby to dualizm empirycznej psychiki i transcendentalnej duchowości, który genetycznie ujęty prowadzi do koncepcji różnych źródeł. Z jednej jednak strony trudno jest - o czym była mowa wyżej - zakładać, że wolność jest cechą emergentną nadbudowaną nad światem empirii (że po prostu rozwinęła się w toku ewolucji materialnego wszechświata),

\footnotetext{
11 H.U. von Balthasar, Teodramatyka 2., cz.1., s. 199.
} 
illusory, based on the principle that we think we are responsible for anything because we do not realize that everything we have done, we were bound to do.

Since we talk about motivations and the acts of free decision which crown them, let us also note that the motivation of human acts must always be provided (apart from desire, predilection, etc.) by reason, i.e., by the instance which makes it possible to discern good and evil in the moral sense. For, as Balthasar observes aptly "If freedom situates itself unilaterally in reason (Stoa), or in the will itself (Scotus, Descartes' tendency, Rousseau, et al.), one always descends below humanity, to the level of instinct." ${ }^{11}$ Instinct (desire) does not have to understand its wanting, but morality demands recognising between good and evil. Purely rational recognition alone, however, is not sufficient for virtue: the good (contrary to ethical intellectualism) must also be desired. Although it is not entirely out of the question that the highest freedom comes from the knowledge of the Good itself, for then one wants nothing more than the Good itself.

Given that freedom does not fit into the deterministic order of nature, perhaps the transcendentalists are right to oppose the transcendental sphere of practicality in man, in which freedom "rules", to the empirical sphere of nature. But whence, one might ask, this "schism in human nature", this inconsistency of freedom and causality? Synchronically, it would be the dualism of the empirical psyche and transcendental spirituality, which conceptualised genetically leads to the concept of different origins. On the one hand, however, it is difficult - as mentioned above - to assume that freedom is an emergent quality superadded to the empirical world (that it simply developed in the course of the evolution of the material universe), and on the other - perhaps even more difficult - to assume that nature is a "derivative" of human freedom. For nature, even in the face of the power of the human spirit, which is great in some of its manifestations, is too powerful to be measured by the finite human spirit, ever grounded in its freedom. The thought that perhaps both

${ }^{11}$ H.U. von Balthasar, Theo-Drama 2, vol. 1, p. 199. 
a z drugiej - jeszcze bodaj trudniej - zakładać, że przyroda jest „pochodną" ludzkiej wolności. Przyroda bowiem - nawet wobec wielkiej w niektórych swych manifestacjach siły ludzkiego ducha - jest zbyt potężna, aby mierzyć ją miarą skończonego i zawsze w swej wolności uziemionego ducha człowieka. Myśl o tym, że - być może - zarówno przyroda wraz z ,uziemionym” w niej wolnym duchem ludzkim pochodzi od jakiejś Wolności Absolutnej (od Nieuwarunkowanego), nasuwa się niemalże automatycznie. Transcendentalistyczne założenie, że mamy w człowieku zasadniczą odrębność sfery praktycznej, w której „rządzi” wolność, od sfery empirycznej, gdzie dominuje bez reszty konieczność, bez próby wyjaśnienia genezy tego stanu rzeczy jest nazbyt arbitralne i nie przekonuje. Nie przekonuje choćby w tym sensie, że człowiek w swej jednostkowej konkretności jawi się tak mocno uwikłany w przyrodę, że wytłumaczenie tego, jak jest możliwe, aby był on zarazem wolny w decyzjach swej woli, staje się czymś niezbędnym. Wprawdzie odwoływanie się do łaski wolności, jaką swemu stworzeniu miałby udzielić Bóg, dla wielu może wydawać się niezadowalające, lecz jeśli tak sądzą, niech wytłumaczą, skąd wziąć by się mogła w przyrodzie ludzka wolność, niech pokażą mechanizm, który ją generuje. Sądzę, że tak niezbędna nam do życia (czy też raczej - do współżycia) wolność jest jedną z największych Tajemnic bytu. Ponieważ trudno jest uznać, że człowiek sam z siebie ma aż taką moc, aby ukonstytuować własną wolność, wypada zgodzić się ze stwierdzeniem Balthasara: „[...] nie możemy zaprzeczyć, że wprawdzie nie jesteśmy nicością, ale nie jesteśmy też Bogiem; nie możemy także zaprzeczyć istnienia dobra i zła, a w konsekwencji musimy przyjąć istnienie wolności stworzonej”'12.

Z tych rozważań można wyciągnąć jeszcze jeden wniosek ogólny: założenie istnienia ludzkiej wolności - ponieważ w żaden sposób nie można go umotywować naturalistycznie - jest jedną z podstawowych przesłanek idealizmu filozoficznego - w szczególności w jego obiektywnej, teistycznej postaci. Teologia chrześcijańska mówi zaś wprost - wyrażając to słowami Karla Bartha - że ,[...] to, co człowiek zna

${ }_{12}$ H.U. von Balthasar, Teodramatyka 2, cz. 1., s. 57. 
the nature and the free human spirit "grounded" in it come from some Absolute Freedom (from the Unconditioned) seems virtually automatic. The transcendentalist assumption that we have in man a fundamental separateness of the practical sphere, in which freedom "rules", from the empirical sphere, where necessity dominates absolutely, without any attempt to explain the genesis of this state of affairs, is too arbitrary and not convincing. It does not convince in the sense that man, in his individual concreteness, appears to be so deeply entangled in nature that it becomes necessary to explain how it is possible for him to be free in the decisions of his will. Admittedly, it may seem unsatisfactory to many to appeal to the grace of freedom that God would grant to his creatures, but if they think so, let them explain where human freedom could come from in nature, let them show the mechanism that generates it. I think that the freedom so necessary for us to live (or rather to coexist) is one of the greatest Mysteries of being. Since it is difficult to acknowledge that man of himself has such a power to constitute his own freedom, one has to agree with Balthasar's statement: "[...] we cannot deny that, although we are not nothingness, neither are we God; neither can we deny the existence of good and evil, and consequently we must accept the existence of created freedom." 12

From these considerations, another general conclusion can be drawn: the assumption of the existence of human freedom - since it cannot in any way be justified in a naturalistic manner - is one of the basic premises of philosophical idealism, particularly in its objective, theistic form. Christian theology, on the other hand, says explicitly in the words of Karl Barth that "[...] what man knows and experiences as his own freedom, he experiences precisely in the freedom which has been given to him and created for him by the fact that Jesus Christ intercedes for him with God. This is thus a great divine b 1 e s s i n g [...]."13 Guardini further writes: "From

${ }^{12}$ H.U. von Balthasar, Theo-Drama 2, vol. 1, p. 57.

13 Karl Barth, Dogmatics in Outline, transl. Ivonna Nowicka, Wydawnictwo Naukowe Semper 1994, p. 91. 
i przeżywa jako własną wolność, to przeżywa właśnie w swobodzie, która mu dana i dlań stworzona przez fakt, że Jezus Chrystus wstawia się za nim u Boga. Jest to więc wielkie d o b r o d z i e j s t w o Boże [...]”13. Guardini pisze zaś: „Z tego źródła (źródła, które stwarza w człowieku Duch Święty - M.Ł.) wywodzi się zdolność człowieka do zapoczątkowywania rzeczy, zdolność będąca darem Bożym, a jednocześnie czymś najbardziej własnym człowieka. W tym punkcie przenikają się nawzajem dwa zjawiska: wolności i łaski [...]"14.

\section{WOLNOŚĆ JAKO DAR I KONIECZNY ELEMENT STWORZENIA}

Biorąc pod uwagę relację między Bogiem a stworzeniem i będąc $\mathrm{w}$ zasadniczej zgodzie $\mathrm{z}$ teologami chrześcijańskimi należy stwierdzić, że wolność człowieka jako podstawa jego odpowiedzialnego działania jest koniecznym elementem stworzonego przez Boga świata. Świat, w którym nie byłoby wolności ani odpowiedzialności do niczego nie byłby Bogu ,potrzebny"15. Jeśli założyć za wieloma teologami, że powodem stworzenia świata jest boska Miłość, która pożąda realizacji, to ta ostatnia może mieć miejsce tylko wobec istoty wolnej, obdarzonej sumieniem, błądzącej i odpowiedzialnej. Jak pisze Hegel: „,To, co wolne, istnieje tylko dla tego, co wolne; tylko dla wolnego człowieka istnieje również ktoś inny jako wolny"li. Te bardzo ważne słowa (także w kontekście społecznego stosunku panowania i niewoli) teologicznie można strawestować tak: ponieważ Bóg jest w najwyższym stopniu wolnym - ponieważ Jego Wola jest Wolnością samą - to, co powołuje on do istnienia, stworzenie, musi być wolne.

${ }^{13}$ Karl Barth, Dogmatyka w zarysie, tłum. Ivonna Nowicka, Wydawnictwo Naukowe Semper 1994, s.91.

14 R. Guardini, Wolność-łaska-los, s. 82.

15 Cudzysłów bierze się stąd, iż Bogu niczego brakować nie może, a poprzez dobrowolne stworzenie, które jest aktem jego absolutnie wolnej Miłości, niczego On nie zyskuje ani nic nie traci.

${ }^{16}$ G.W.F. Hegel, Wyktady z filozofii religii, Tom II, Wydawnictwo Naukowe PWN, Warszawa 2007, s. 256. 
this source (the source which the Holy Spirit creates in man - clarifies the author of the paper) comes man's capacity to initiate things, a capacity which is a gift of God and at the same time something most intrinsic to man. At this point two phenomena intermingle: freedom and grace [...]."14

\section{FREEDOM AS A GIFT AND ESSENTIAL PART OF CREATION}

Taking into account the relationship between God and creation, and remaining in fundamental agreement with Christian theologians, it has to be said that man's freedom as the basis of his responsible action is an essential element of the world created by God. A world without freedom and responsibility would not be "necessary" for God. ${ }^{15}$ If we assume, following many theologians, that the reason for the creation of the world is divine Love, which desires realization, the latter can only take place towards a being who is free, endowed with a conscience, erring and responsible. As Hegel writes „what is free exists only for that which is free; only for the free man does someone else also exist as free."16 These very important words (also in the context of the social relation between domination and captivity) can be travestied theologically as follows: since God is in the highest degree free - for His Will is Freedom itself - what He calls into being, namely creation, must be free. The creature finds its freedom in man, who is its (the creature's) quintessence (this is, one might say, a kind of "proof" that man is a free being, meaning a being capable of choosing according to the criterion of reason). Man, on the other hand, finds the confirmation of his freedom first of all

14 R. Guardini, Freedom, Grace, and Destiny, p. 82.

15 The inverted commas are used here to show that God cannot lack anything, and that through his voluntary creation, which is an act of his absolutely free Love, he neither gains nor loses anything.

${ }^{16}$ G.W. F. Hegel, Lectures on the Philosophy of Religion, Vol. II, Wydawnictwo Naukowe PWN, Warsaw 2007, p. 256. 
Znajduje ono swą wolność w człowieku, który jest jego (stworzenia) kwintesencją (jest to - można powiedzieć - swoisty „dowód” na to, że człowiek jest istotą wolną, tj. zdolną wybierać według kryterium rozumu). Człowiek zaś potwierdzenie swojej wolności odnajduje przede wszystkim w Bogu (gdyż od niego pochodzi), a dopiero wtórnie w innym człowieku.

Wolność jest zatem darem Boga, jak pisze Barth: „Wolność stanowi wielki podarunek Boga, dar spotkania z Nim"'17. Przy czym dar ten należy rozumieć zarówno w sensie ,wolności do" - wolności do podejmowania określonych decyzji w oparciu o rozumowe rozeznanie rzeczywistości, tj. bez zniewalającego przymusu ze strony mechanizmów naturalnych, którym człowiek w znacznej mierze podlega - jak i ,wolności od” - wolności od strachu, który - w warunkach naturalnego bytowania człowieka - w zasadzie sprowadza się do strachu przed - mówiąc za Heglem - ,panem absolutnym”, czyli śmiercią. Przy czym - jak należałoby dodać - nie tylko o wymiar biologiczny tutaj chodzi, lecz przede wszystkim moralny. Nie tyle bowiem fakt końca jednostkowego życia jest przerażający, co jego bezsensowność, pustka aksjologiczna i beznadzieja, w jakiej dokonywałby się żywot ludzki, gdyby nie było gwarancji wiecznego zachowania wartości (miłości, dobra, sprawiedliwości itp.) realizowanych w ludzkim życiu, lecz także - odpowiedzialności za popełnione zło oraz nieustannej i niekończącej się możliwości odkupienia wyrządzonych krzywd oraz przebaczenia za .krzywdy doznane.

Teologicznemu postrzeganiu człowieka jako istoty wolnej przeciwstawia się perspektywa deterministyczna. Zgodnie z tą ostatnią nie ma sprzeczności w następującej konstrukcji: jesteśmy jednoznacznie zdeterminowanymi automatami obdarzonymi wszakże świadomością, tj. możliwością poznawczego odzwierciedlania świata i siebie samych (samoświadomość). Przy czym w aspekcie wewnętrznego poczucia bycia wolnym (a intuicja taka na ogół ludziom towarzyszy w odniesieniu do wielu działań, na jakie się decydują) odzwierciedlenie to może być błędne - prowadzić do nieprawdziwych wniosków.

${ }_{17}$ K. Barth, Dogmatyka ..., s. 15. 
in God (because he originates from God), and only secondarily in another human being.

Freedom is therefore a gift from God, as Barth writes: "Human freedom is indeed the gift of God, the gift of an encounter with Him." ${ }^{\prime 17}$ However, this gift must be understood both in terms of "freedom to [act]", in other words, the freedom to make certain decisions on the basis of a rational appraisal of reality, that is, without the compelling constraint of natural mechanisms to which man is to a large extent subjected, and in terms of "freedom from", in other words, freedom from fear which, in the conditions of man's natural existence, basically amounts to the fear of - to use Hegel's term "the absolute master", namely death. It should be added, though, that it is not only the biological dimension that is at stake here, but above all the moral one. For it is not so much the fact of the end of individual life that is frightening as its meaninglessness, the axiological emptiness and hopelessness in which human life would take place if there were no guarantee of the eternal preservation of values (love, goodness, justice, etc.) realized in human life, but also of responsibility for the evil committed and of the constant and never-ending possibility of redemption for the wrongs done and of forgiveness for the wrongs suffered.

The theological view of man as a free being is opposed to the deterministic perspective. According to the latter, there is no contradiction in the following construction: we are unequivocally determined automatons endowed, after all, with cognitive awareness, i.e., with the ability to cognitively reflect the world and ourselves (selfawareness). However, in terms of the internal sense of being free (and this intuition generally accompanies many of the actions that people decide to take), this reflection can be erroneous and lead to false conclusions. In the case of self-awareness, we may falsely believe that we are free. But can self-awareness be mistaken in our sense of being free in our decisions? After all, it meets Brentan's criterion of selfevident judgment: identity of subject and object (I say of myself that

\footnotetext{
${ }^{17}$ K. Barth, Dogmatics..., p. 15.
} 
W przypadku samoświadomości możemy fałszywie sądzić, że jesteśmy wolni. Czy jednak samoświadomość może się mylić w naszym poczuciu bycia wolnym w swych decyzjach? Przecież spełnia ona Brentanowskie kryterium sądu oczywistego: identyczność podmiotu i przedmiotu sądu (ja o samym sobie stwierdzam, że jestem wolny). Można wszakże przypuścić, że są pewne nieuświadomione mechanizmy rządzące naszym zachowaniem, różne ukryte tendencje jednoznacznie determinujące nasze działania. W zasadzie - postrzegając człowieka w perspektywie tylko przyrodniczej - trudno jest uciec od determinizmu. Nic tu nie zmienia - jak to wskazywałem już wyżej - indeterminizm (determinizm statystyczny), o jakim mówi się w mechanice kwantowej. On nie jest w stanie uzasadnić aksjologicznej wolności podmiotu, a jedynie wprowadza do działania przyrody (w tym - ludzkich organizmów) pierwiastek ,przypadkowości” czy nieokreśloności. A wolność nie może być ani przypadkowa ani nieokreślona.

\section{WOLNOŚĆ JAKO WZGLĘDNA AUTONOMIA}

O ile wolność Boga jest autonomią absolutną, o tyle ludzka wolność jest li tylko względną autonomią wyższej warstwy ontycznej społecznej, duchowej. Zatrzymajmy się przy tej drugiej. „Królestwo wolności”, jakie realizuje człowiek w świecie moralności i kultury, zawsze zasadza się na „królestwie konieczności”, którym jest przyroda, stanowiąca egzystencjalne (ontyczne) podłoże ludzkiej duchowości. Ta ostatnia nie może istnieć bez pierwszej. Mimo to jednak nie podlega wszystkim jej determinacjom ${ }^{18}$. Artysta np. jest organizmem, którego dotyczą wszystkie - bardziej bądź mniej przykre - determinacje przyrody, a jednak jego duch artystyczny w tym zakresie,

18 Dlatego słusznie stwierdza Guardini, że wolność ludzką należy plasować pomiędzy dwiema skrajnościami: determinizmem, który w ogóle zaprzecza istnieniu wolności, a absolutyzmem, który próbuje przypisać człowiekowi - właściwą tylko Bogu - wolność absolutną. Z człowieka nie można robić ani samej tylko cząstki natury, ani - tym bardziej - Boga (R. Guardini, Wolność-łaska-los, s. 69). 
I am free). After all, one can suppose that there are some unconscious mechanisms that govern our behavior, some hidden tendencies that unambiguously determine our actions. In principle, looking at human beings from a purely natural perspective, it is difficult to escape determinism. As I pointed out above, indeterminism (statistical determinism), which is spoken about in quantum mechanics, does not change anything here. It does not justify the axiological freedom of the subject, but only introduces an element of "randomness" or indefiniteness into the activity of nature (including human organisms). And freedom can be neither accidental nor indeterminate.

\section{FREEDOM AS RELATIVE AUTONOMY}

As much as God's freedom is an absolute autonomy, human freedom is only a relative autonomy of a higher ontic-social, spiritual. Let us concentrate on the latter. The "kingdom of freedom" which man realizes in the world of morality and culture is always founded on the "kingdom of necessity", namely nature, which constitutes the existential (ontic) basis of human spirituality. The latter cannot exist without the former. Nevertheless, it is not subject to all its determinations. ${ }^{18}$ The artist, for example, is an organism affected by all the - more or less unpleasant - determinations of nature, and yet the artistic spirit is free and autonomous to the extent that it composes the contents of a thoughtful work and creates a new intentional reality. One could say that freedom in the case of man involves the independence of at least some mental content from the laws of nature. However, it is difficult to explain ontologically where this possibility comes from within the framework of materialism. For freedom is a feature of consciousness endowed with will. This

18 This is why Guardini rightly states that human freedom must be placed between two extremes, i.e. between determinism, which denies the existence of freedom altogether, and absolutism, which seeks to ascribe to man an absolute freedom proper only to God. Man cannot be made into a mere particle of nature, let alone God. (R. Guardini, Freedom, Grace, and Destiny, p. 69). 
w jakim komponuje treści zamyślonego dzieła, stwarzając nową intencjonalną rzeczywistość, jest wolny, autonomiczny. Można powiedzieć, że wolność w przypadku człowieka to niezależność niektórych przynajmniej treści myślowych od praw przyrody. Skąd zaś bierze się taka możliwość, trudno jest ontologicznie wyjaśnić w ramach materializmu. Wolność jest bowiem cechą świadomości obdarzonej wolą. Cecha ta polega na tym, że może ona kreować różne „światy” (np. intencje lub czyny moralne) - wprawdzie nie wbrew determinizmowi i konieczności naturalnej, lecz obok niej - czy raczej „ponad nią". Przyjmujemy mianowicie, że kondycja fizyczna ludzi wolnych w zakresie duchowym (a tylko w nim mogą oni być wolni) nie określa - a w każdym razie nie musi być czynnikiem decydującym - ich świadomych wyborów ani też treści, jakimi zapełnia się świadomość pod wpływem tych rozstrzygnięć. Oczywiście nie ma wyborów nieuwarunkowanych - zasada powszechnego zdeterminowania (,,racji dostatecznej”) obowiązuje we wszystkich obszarach bytowości. Podlega jej zatem także myśl ludzka. Moralność, filozofia (nauka) czy sztuka też podlegają koniecznościom. Mamy w nich bowiem, odpowiednio: ,imperatywy kategoryczne”, związki logiczne, „prawa harmonii" (współwystępowania i przenikania się konsonansów i dysonansów). Tyle tylko, że są to „konieczności własne”, determinacje autonomiczne (w swych treściach) względem konieczności przyrodniczej. Duch jest w takich przypadkach u siebie”. „Wolne bowiem - powiada Schelling - jest tylko to, co działa wedle praw własnej istoty i czego nie determinuje nic innego z wnętrza lub zewnętrza"'19.

W tym kontekście nie do utrzymania jest potoczne rozumienie wolności, wedle którego - jak pisze Schelling - ,[...] polega ona na zupełnie niezdeterminowanej zdolności wyboru bez określonych racji jednej z dwu przeciwstawnych możliwości $[\ldots]^{20}$. Przy takiej wolności „osioł Buridana” pada z głodu. Ponadto pojęcie to wprowadza absolutną przypadkowość, która jest kategorią - powiedziałbym nieontologiczną, ontycznie pustą. Jak stwierdza Schelling: „Przypadek

\footnotetext{
19 F.W. J. Schelling, Filozoficzne badania ..., s. 90.

20 Tamże, s. 86.
} 
feature consists in the fact that it can create different "worlds" (e.g., intentions or moral acts) - not in defiance of determinism and natural necessity, but alongside it, or rather "above it." Namely, we assume that the physical condition of free people in the spiritual sphere (and it is only in this sphere that they can be free) does not determine - and in any case need not be a decisive factor - their conscious choices or the content with which consciousness is filled under the influence of these choices. There are clearly no unconditioned choices the principle of universal determination ("sufficient reason") holds true in all areas of being. Human thought is therefore also subject to it. Morality, philosophy (science) or art are also subject to necessity. For in them we have, respectively: "categorical imperatives", logical relationships, "laws of harmony" (coexistence and interpenetration of consonances and dissonances). Except that these are „our own necessities", determinations autonomous (in their contents) in relation to the natural necessity. The spirit is at home in such cases." "For free," says Schelling, "is only that which acts according to the laws of its own being and which is not determined by anything else from inside or outside. ${ }^{19}$

In this context, the colloquial understanding of freedom is untenable, according to which, as Schelling writes, "[...] it consists in the utterly indeterminate capability to choose, without definite reasons, one of two opposing areas [...]. ${ }^{20}$ With such freedom, "Buridan's donkey" starves to death. Moreover, this concept introduces absolute randomness, which is a category, according to the author, nonontological, and ontically empty. As Schelling states, "But chance is impossible, it contradicts reason and the necessary unity of the whole, and if freedom cannot be saved except by attributing absolute randomness to actions, it cannot be saved at all." ${ }^{21}$ Regarding freedom, the German philosopher introduces the concept of "higher necessity" ("inner necessity"), which differs both from chance (as a generally

\footnotetext{
19 F.W. J. Schelling, Philosophical Investigations..., p. 90.

20 Ibid, p. 86.

${ }^{21}$ Ibid, p. 87-88.
} 
jednak jest niemożliwy, przeczy rozumowi i koniecznej jedności całości, jeśli zaś wolności nie można uratować inaczej niż przez przypisanie działaniom zupełnej przypadkowości, to nie można jej uratować w ogóle" 21 . Niemiecki filozof wprowadza w odniesieniu do wolności pojęcie „wyższej konieczności” („konieczności wewnętrznej”), która różni się zarówno od przypadku (jako w ogóle - podkreślmy - wątpliwej ontologicznie kategorii), jak i od przymusu czy konieczności zewnętrznej determinacji ${ }^{22}$. Odnosząc powyższe do moralności jako najważniejszej bodaj sfery, w której realizuje się wolność, możemy - za Schellingiem - stwierdzić: „Wolne działanie wynika bezpośrednio z tego, co w człowieku inteligibilne. Z konieczności jest jednak określonym działaniem [...] dobrym albo złym"23. Można też powiedzieć ogólniej, że wolne działanie z konieczności jest dobre albo złe. Nie ma ono możliwości uchylenia się od wyboru jednej z tych opozycji. Takie rozumienie wolności potwierdza też Marcel, który utrzymuje, że wolność ludzka nie realizuje się w stanie niezdeterminowania czy zobojętnienia i że nie jest prawdą, iż ,,[...] wolność ma bezwzględny charakter wówczas, gdy racje tego czy innego wyboru są tak słabe, jak to tylko możliwe"24.

Za konstytutywny moment wolności skończonej należy uznać możliwość transcendowania samej siebie (przekraczania własnych ograniczeń, wychodzenia poza granice własnego uziemienia) - przez co należy rozumieć przede wszystkim doskonalenie się moralne. Balthasar uważa przy tym, że każdorazowy akt takiej transcendencji „[...] może zaistnieć tylko w następstwie darmowego otwarcia się Wolności Nieskończonej" 25 , w której - że tak powiem - zanurzona jest wolność skończona. Można to rozumieć tak, że np. poświęcenie życia dla kogoś - jako radykalny akt moralnego transcendowania

21 Tamże, s. 87-88.

22 Tamże, s. 88.

23 Tamże, s. 89.

${ }^{24}$ Marcel Gabriel, Tajemnica bytu, tłum. Małgorzata Frankiewicz, przedm. Karol Tarnowski, Wydawnictwo Znak, Kraków 1995, s. 330.

${ }^{25}$ H.U. von Balthasar, Teodramatyka 2. Osoby dramatu, cz. 1., s. 300. 
- let us emphasize - ontologically questionable category) and from compulsion or the necessity of external determination ${ }^{22}$. Applying these considerations to morality as perhaps the most important sphere in which freedom is realized, we can, following Schelling, state: "Free action follows immediately from an intelligible being. (...) [T] he real and vital conception of freedom is that it is a possibility of good and evil." ${ }^{23}$ It may also be said more generally that free action is necessarily either good or evil. It has no possibility of evading the choice of one of these oppositions. This understanding of freedom is confirmed by Marcel, who maintains that human freedom is not realized in a state of indetermination or indifference, and that it is not true that "[...] freedom has an absolute character when the reasons for this or that choice are as weak as possible." ${ }^{4}$

The constitutive moment of finite freedom is the possibility of transcending itself (transcending its own limitations, going beyond the limits of its own grounding), which means, above all, moral perfection. Balthasar believes that each act of such transcendence "[...] can only come about as a result of the gratuitous opening up of Infinite Freedom"25, in which finite freedom is, so to speak, immersed. This can be understood in such a way that, for example, sacrificing one's life for someone - as a radical act of moral transcendence of one's own limitations - makes sense only in the perspective of the eternal God, not in the sense that He can reward the sacrifice (compensate the suffering with some kind of "higher pleasure"), but that only in the face of the ultimate Sense determined by Infinite Freedom does the sacrifice make sense. And it makes sense only when it is not merely an emotional reflex of a psychically endowed organism, which will pass away along with every natural thing (also along with the person for whom we sacrifice our lives, and with possible torturers), but as

\footnotetext{
22 Ibid, p. 88 .

23 Ibid, p. 89.

${ }^{24}$ Marcel Gabriel, The Mystery of Being. translated by Małgorzata Frankiewicz, foreword by Karol Tarnowski, Znak Publishing House, Cracow 1995, p. 330.

${ }^{25}$ H.U. von Balthasar, Theo-Drama 2, vol. 1, p. 300.
} 
własnych ograniczeń - ma sens tylko w perspektywie odwiecznego Boga - ale nie w tym sensie, że może On nagrodzić poświęcenie (wyrównać cierpienie jakimś rodzajem „wyższej przyjemności”), lecz że tylko w obliczu ostatecznego Sensu wyznaczonego przez Wolność Nieskończoną poświęcenie to ma sens. A ma sens tylko wtedy, gdy nie jest jedynie emocjonalnym odruchem obdarzonego psychiką organizmu, który przeminie wraz z każdą naturalną rzeczą (także wraz z tym kimś, dla kogo życie poświęcamy, oraz z ewentualnymi oprawcami), lecz - jako triumf nad złem - stanowi utrwaloną na wieki wartość, cząstkę absolutnego Dobra. Ludzkie transcendowanie świata, które dokonuje się w perspektywie Boga (Wolności Nieskończonej), zawiera w sobie - jak ujmuje to Balthasar - „moment akosmiczności"26. Można powiedzieć, że człowiek moralny, a tym samym - wolny uzyskuje dystans wobec wszystkiego, co wewnątrzświatowe. Ta zasadnicza dwoistość bycia z konieczności osadzonym w bytowaniu natury, a zarazem przekraczania jej w swej wolności jest charakterystyczna wyłącznie dla człowieka ${ }^{27}$.

Warto podkreślić przy tym dynamizm wolności skończonej, tj. to, że - jako skończona - nie jest ona czymś ukończonym - chyba że w wymiarze eschatologicznym. Jej zanurzenie w Wolności Nieskończonej powoduje, iż - na mocy wolnej decyzji tej ostatniej - wolność skończona immanentnie zawiera „współczynnik nieskończoności”, tzn. ciągle może wzrastać, gdyż Wolność Nieskończona „[...] otwiera jej samą siebie, jako przestrzeń jej realizacji” ${ }^{28}$. Z tego otwarcia wolność skończona czerpie moc do samotranscendencji - do nieustannego doskonalenia się.

26 Tamże, s. 330.

${ }^{27}$ Nie znajdujemy jej w zasadzie w świecie zwierząt - chyba że w jakiejś rudymentarnej postaci.

28 Tamże, s. 226. 
a triumph over evil it constitutes an eternally perpetuated value, a part of the absolute Good. The human transcendence of the world, which takes place in the perspective of God (Infinite Freedom), contains, as Balthasar puts it, "a moment of the acosmicity." ${ }^{26}$ One could say that moral man, and thus free man, acquires a distance from everything that is intrinsic to the world. This fundamental duality of being necessarily embedded in the being of nature and at the same time transcending it in one's freedom is characteristic only of man. ${ }^{27}$

Here it is worth noting the dynamism of finite freedom, i.e. the fact that, as finite, it is not complete except in the eschatological dimension. Its immersion in Infinite Freedom means that, by virtue of the free decision of the latter, finite freedom immanently contains an "infinite coefficient", i.e. it can always grow, because Infinite Freedom "[...] opens itself up to it as the space for its realization." ${ }^{28}$ From this opening, finite freedom draws the power for self-transcendence, for continual self-improvement.

\section{GOD AS THE CONDITION OF FREEDOM}

Nature knows no freedom. Using Hegel's words, spoken in a slightly different context in Lectures on the Philosophy of Religion, Vol. I, it can be said that "a spirit burdened with a natural element does not have the reality that it should have according to its conception." 29 However, what we consider to be a reality compatible with the concept of spirit is freedom. In the light of the above, it must be said that man is free only in one dimension of his existence - in his "spiritual yard" (as a "thinking reed"). Nevertheless, in general terms, he is essentially dependent on nature, and his laborious liberation from the limitations of nature, which undoubtedly takes place throughout

\footnotetext{
26 Ibid, p. 330.

27 We can hardly find it in the animal world, except in some rudimentary form.

${ }^{28}$ Ibid, p. 226.

${ }^{29}$ G.W. F. Hegel, Lectures on the Philosophy of Religion, Vol. I, Wydawnictwo Naukowe PWN, Warsaw 2006, p. 239.
} 


\section{BÓG JAKO WARUNEK WOLNOŚCI}

Przyroda nie zna wolności. Wykorzystując słowa Hegla - wypowiedziane w nieco innym kontekście w Wykładach z filozofii religii (I) - można stwierdzić, że „duch obciążony elementem naturalnym nie ma realności, jaką powinien mieć zgodnie ze swoim pojęciem"29. Dla nas zaś realnością zgodną z pojęciem ducha jest właśnie wolność. W świetle powyższego należ stwierdzić, że człowiek jest wolny tylko w jednym wymiarze swojej egzystencji - na swym ,duchowym podwórku” (jako „trzcina myślaca”). Biorąc jednak rzecz całościowo, jest on zasadniczo zależny od przyrody, a jego - niewątpliwie mające miejsce w historii - mozolne wyzwalanie się od ograniczeń natury napotyka nieprzekraczalne bariery biologiczne. Stąd pełne wyzwolenie człowieka - jeśli rozumieć przez nie wyzwolenie się spod władzy ,pana absolutnego - śmierci - nie może być jego dziełem. „Prometejskie mrzonki” niektórych filozofów (np. marksistowskich, jak choćby Ernst Bloch) są tedy utopiami. Przestają one jednak takimi być, gdy wyzwolenie człowieka będziemy rozumieć bardziej minimalistycznie. Idzie przecież o to - powiedzą oni - aby człowiek w skończoności swojej egzystencji żył jak najdłużej w zdrowiu oraz o to, aby świat przyrody był dlań coraz bardziej ,poręczny” i przydatny, a środowisko społeczne przyjazne i solidarne. Oczywiście człowiek nie byłby człowiekiem, gdyby takie pragmatyczne wyzwolenie (czy raczej - wyzwalanie) nie „zaprawił” potrzebą odpowiedniej dawki dramatyczności, jakiegoś heroizmu, moralnego zmagania się w obronie pewnych ponadindywidualnych wartości - dotyczących np. przyszłych pokoleń, które wcześniej czy później i tak zginą wraz ze zmianą materialnych warunków umożliwiających ich istnienie. August Comte utrzymywał, że organizm społeczny - podobnie jak

${ }^{29}$ G.W. F. Hegel, Wyktady z filozofii religii, Tom I, Wydawnictwo Naukowe PWN, Warszawa 2006, s. 239. 
history, encounters insurmountable biological barriers. Hence man's full liberation - when we understand it as liberation from the power of "the absolute master - death - cannot be his work. The "Promethean dreams" of some philosophers (e.g. Marxists such as Ernst Bloch) are therefore utopias. They cease to be so, however, when we understand human liberation in a more minimalist way. The point is, they say, that man, in the finiteness of his existence, should live as long as possible in health and that the natural world should be increasingly "handy" and useful to him, and the social environment should be friendly and supportive. Of course, man would not be man if such a pragmatic liberation (or rather -a process of liberating) were not "seasoned" with the need for an appropriate dose of drama, some heroism, a moral struggle in defense of certain supra-individual values regarding, for example, future generations that sooner or later will perish anyway along with the change of material conditions that make their existence possible. August Comte maintained that the social organism, like the individual organism, is doomed to decline, and that nothing can change this destiny of people's social existence ${ }^{30}$.

In the latter perspective, the proper and "complete" liberation of man would probably be his non-existence ( non-being, nothingness, "annihilation", "dissolving in the universe"), and along with it the nonexistence of all the values to which he adhered in his "destructive" life. But whoever does not find such a minimalism or negativism of "salvation" sufficient, must turn to a freedom more powerful than the limited autonomy of thinking and moral man, this is the freedom of God. Such a turn to God does not mean that human existence ceases to be dramatic. From a Christian perspective, we should say in the words of Balthasar: "There is only one anthropology: a dramatic one." ${ }^{31}$ The martyrdom and suffering of Jesus Christthe misunderstanding, abandonment, and scorn heaped upon

30 Stefan Sarnowski, Świadomość i czas. O początkach filozofii współczesnej [Eng.: Consciousness and Time. About the Origins of Modern Philosophy], PWN, Warsaw1985, p. 83.

31 H.U. von Balthasar, Theo-Drama 2, vol. 1, p. 322. 
organizm jednostki - skazany jest na upadek i że nic nie jest w stanie zmienić tego przeznaczenia społecznego bytowania ludzi ${ }^{30}$.

W tej ostatniej perspektywie za właściwe i ,pełne” wyzwolenie człowieka należałoby chyba uznać jego nieistnienie (niebyt, nicość, „anihilację”, „rozpłynięcie się we wszechświecie”), a wraz z nim nieistnienie wszystkich wartości, jakim hołdował on w swoim ,straceńczym” życiu. Komu jednak taki minimalizm lub negatywizm „zbawienia” nie wystarcza, ten musi zwrócić się do wolności potężniejszej niż ograniczona autonomia myślącego i moralnego człowieka - do wolności Boga. Takie zwrócenie się ku Bogu nie oznacza, że ludzka egzystencja przestaje być dramatyczna. Z perspektywy chrześcijańskiej należy powiedzieć za Balthasarem: „Istnieje jedna tylko antropologia: dramatyczna"31. Męczeńska śmierć i cierpienie Jezusa Chrystusa - niezrozumienie, opuszczenie i zgorszenie, jakie na Niego spadły - są absolutnym pierwowzorem tej dramatyczności. A jak usilnie podkreśla Kierkegaard, chrześcijaństwo nie polega na triumfie, wywyższeniu i admiracji (fałszywość „Kościoła triumfującego"), lecz na naśladowani Chrystusa, co jest równoznaczne z walką i uniżeniem ${ }^{32}$. Chrystus się uniżył, a jako samouniżony nie potrzebuje admiratorów, lecz naśladowców. Uniżenie Chrystusa ma zatem swe konsekwencje dla Jego wyznawców: ich doczesną drogą ma być Jego naśladowanie, które w warunkach doczesności zawsze jest dramatyczne. $Z$ tej perspektywy eschatologiczno-soteriologiczne wywyższenie ludzi, którego zapowiedzią jest zmartwychwstały i triumfujący Chrystus, wymaga tragicznej dramatyczności ludzkiego życia. Życia uniżonego i cierpiącego, lecz prowadzonego przez Opatrzność do ostatecznego triumfu nad grzechem i śmiercią. Triumf w chrześcijaństwie jest zawsze „ostatnim słowem” - a do tego jest warunkowany Bożą łaską. Dlatego nie ma chyba w dziedzinie

30 Stefan Sarnowski, Świadomość i czas. O początkach filozofii współczesnej, PWN, Warszawa 1985, s. 83.

31 H.U. von Balthasar, Teodramatyka 2. cz. 1., s. 322.

32 S. Kierkegaard, Wprawki do chrześcijaństwa, tłum. Antoni Szwed, Wydawnictwo ANTYK, Kęty 2002, s. 164- 209. 
him-are the absolute prototype of this drama. And as Kierkegaard strenuously emphasizes, Christianity is not about triumph, exaltation, and admiration (the falsity of the "triumphant church"), but about following Christ, which is tantamount to struggle and humility ${ }^{32}$. Christ humbled himself, and as self-abashed, he needs no admirers but followers. The humbling of Christ, therefore, has its consequences for his followers: their temporal path is to follow his example, which under temporal conditions is always dramatic. From this point of view, the eschatological-soteriological exaltation of human beings, heralded by the risen and triumphant Christ, requires the tragic drama of human life. A life humbled and suffering, but led by Providence to the final triumph over sin and death. Triumph in Christianity is always the "last word"-and it is conditioned by God's grace. Therefore, there is perhaps nothing more unnatural and false in the realm of religiosity than the triumphalism of Christians (the Church). Both humility and exaltation must be embraced by the Christian in humility.

Hegel understands the issue in a similar way, when - in the context of Christ's saving passion - he writes: "[...] it is not morality in general, what the subject thinks and wants in and of itself, but the infinite relation to God, to the present God, the certainty of the Kingdom of God, not the solace to be found in morality, morality, or conscience, but the solace beyond which there is nothing higher - the absolute relation to God himself." 33

Thus, what the finite spirit can find in itself, e.g., a moral attitude toward others, is not sufficient for actual, real liberation. For all the "ways of appeasement", as Hegel puts it, are of a subordinate kind. Hence it may be assumed that the maximal goal of the aspiring will to freedom is the "present presence" of God, and that the basis of love for human beings is "the consciousness that God is love"34.

32 S. Kierkegaard, An Introduction, transl. Antoni Szwed, ANTYK Publishing House, Kęty 2002, pp. 164- 209.

33 G.W. F. Hegel, Lectures (II), p. 305.

34 Ibid. 
religijności nic bardziej nienaturalnego i fałszywego niż triumfalizm chrześcijan (Kościoła). Zarówno uniżenie, jak i wywyższenie chrześcijanin winien przejmować w pokorze.

Podobnie zresztą rzecz rozumie Hegel, gdy - w kontekście zbawczej męki Chrystusa - pisze: ,[...] nie chodzi o moralność w ogóle, o to, co myśli i czego chce podmiot w sobie i sam z siebie, lecz o nieskończony stosunek do Boga, do teraźniejszego Boga, o pewność Królestwa Bożego, nie o ukojenie, jakie można znaleźć w moralności, obyczajności, czy też w sumieniu, lecz o ukojenie, poza którym nie ma niczego wyższego - o absolutny stosunek do samego Boga"33.

Tak więc do faktycznego, rzeczywistego wyzwolenia nie wystarczy to, co skończony duch może znaleźć w samym sobie - np. moralny stosunek do innych. Wszystkie bowiem - jak to ujmuje Hegel - „sposoby ukojenia” są podrzędnego rodzaju. Można zatem przyjąć, że maksymalnym celem, jaki stawia sobie aspirująca do wolności wola, jest „teraźniejsza obecność” Boga, a podstawą miłości do ludzi jest „świadomość, że Bóg jest miłościa”" ${ }^{34}$.

Ponieważ wolność człowieka permanentnie uwikłana jest w konieczność przyrody, której własnymi siłami uchylić on nie może, $\mathrm{W}$ koncepcjach antropologii religijnej uznaje się na ogół, iż to Bóg „W swej istocie jest do tego stopnia nieskończenie wolny, że tylko On może umożliwić, udźwignąć i spełnić wolność ludzką"35. Człowiekowi potrzebny jest gwarant wolności - jego wolność jest nieautonomiczna. Jeśli chcemy postrzegać człowieka skrajnie redukcjonistycznie, tj. jako byt czysto przyrodniczy, to nie ma w nim miejsca na wolność. Ponieważ wolność człowieka w świecie przyrody jest rzeczą tajemniczą - w zasadzie niewyjaśnianą w oparciu o mechanizmy naturalne - Bóg zdaje się być „naturalnym” kandydatem

\footnotetext{
33 G.W. F. Hegel, Wykłady (II), s. 305.

34 Tamże.

35 Alexandre Ganoczy, Stwórczy człowiek i Bóg stwórca, Instytut Wydawniczy PAX, Warszawa 1982, s. 111.
} 
Since man's freedom is permanently entangled in the necessities of nature, which it is impossible for him to escape by his own efforts, the concept of religious anthropology generally recognizes that it is God "who in his essence is so infinitely free that only he can make human freedom possible, bearable and fulfilling." 35 Man needs a guarantee of freedom - his freedom is non-autonomous. If we wish to view man in an extremely reductionist way, i.e., as a purely natural being, there is no room for freedom in him. Since human freedom in the natural world is a mysterious thing - in principle, unexplained on the basis of natural mechanisms - God seems to be a "natural" candidate for the guarantor of human freedom ${ }^{36}$. For God to make an entity entangled in nature (man) free in the fundamental dimensions of its existence (morality, knowledge, art) is nothing. Anyway, this is the viewpoint of faith, which, as Ganoczy writes, "[...] sees the certainty of being and becoming free only in being bound to a free God." ${ }^{37}$ Thus, it can be said that the power of human freedom - if that freedom occurs at all (and it should if we are to treat ourselves as spiritual entities and not as mere natural objects) - comes from God.

\section{FREEDOM BEYOND GOD. AN ATHEISTIC POINT OF VIEW (KARL MARX)}

By contrast, in all atheistic anthropologies (humanistic atheism), such as Karl Marx's "Enlightenment" anthropology, God is seen not as the giver of "value and freedom", but as a limitation and threat to human freedom. Such thinking is utopian and "wishful thinking" insofar as it assumes that man is capable of achieving freedom by himself if he only recognizes natural necessities. From the atheistic point of view, however, it is claimed that it is precisely

35 Alexandre Ganoczy, Stwórczy człowiek i Bóg stwórca [The Creator Man and the Creator God], Instytut Wydawniczy PAX, Warsaw 1982, p. 111.

${ }^{36}$ As the symbolic biblical account states, it was Yahweh, who brought the Israelites up out of the land of Egypt, „out of the house of bondage.”

37 Alexandre Ganoczy, Stwórczy człowiek i Bóg stwórca, p. 122. 
na gwaranta ludzkiej wolności ${ }^{36}$. Cóż to jest dla Boga sprawić, aby byt uwikłany w przyrodę (człowiek) był zarazem w zasadniczych wymiarach swego istnienia (moralność, wiedza, sztuka) wolny. Taki jest przynajmniej punkt widzenia wiary, która - jak pisze Ganoczy „[...]widzi pewność bycia i stawania się wolnym jedynie w związaniu się z wolnym Bogiem" " wolności - jeżeli ta ma w ogóle miejsce (a mieć powinna, jeśli mamy traktować siebie jako duchowe podmioty, a nie jako zwykłe obiekty przyrodnicze) - pochodzi od Boga.

\section{WOLNOŚĆ POZA BOGIEM. ATEISTYCZNY PUNKT WIDZENIA (KAROL MARKS)}

Z powyższym ujęciem kontrastują wszelkie antropologie ateistyczne (ateizmy humanistyczne), w których - jak np. w „oświeceniowej” antropologii Karola Marksa - Boga postrzega się nie jako dawcę „wartości i wolności”, lecz jako ograniczenie i zagrożenie dla ludzkiej wolności. Myślenie takie jest o tyle utopijne i „życzeniowe”, o ile zakłada, że człowiek sam z siebie zdolny jest do osiągnięcia wolności, jeśli tylko rozpozna konieczności przyrodnicze. Z ateistycznego punktu widzenia twierdzi się zaś, że to właśnie religijne oczekiwanie wolności totalnej, całkowitego wybawienia od konieczności przyrodniczej - zbawienia i zmartwychwstania w nowym ciele i w radykalnie przemienionym kosmosie, który już więcej nie przeciwstawia się - jako „królestwo konieczności” - ludzkiej wolności - jest utopią. Człowiek - rozwijając w toku ewolucji biologicznej oraz społecznej swoją myśl - jest w stanie coraz bardziej zapośredniczać swój bezpośredni stosunek do przyrody (np. libidialne $i d$ zapośredniczone kulturowym super ego), a tym samym sublimować swoje relacje z drugim człowiekiem. Rozwijając zaś myśl techniczną i jej wcielenie - technikę - człowiek zyskuje sporo przewag fizycznych nad

\footnotetext{
36 Jak podaje symboliczny przekaz biblijny, to Jahwe wywiódł Izraelitów z Egiptu - ,z domu niewoli”.

37 Alexandre Ganoczy, Stwórczy człowiek i Bóg stwórca, s. 122.
} 
the religious expectation of total freedom, of complete deliverance from natural necessity - salvation and resurrection in a new body and in a radically transformed cosmos which no longer opposes as a "kingdom of necessity" - human freedom - that is utopian. Man - by developing his thought in the course of biological and social evolution - is able to increasingly mediate his direct relation to nature (e.g., the libidinal $i d$ mediated by the cultural super ego) and thereby sublimate his relations with the other man. In turn, by developing technical thought and its embodiment, technology, man gains many physical advantages over his biological nature - over his physical limitations. And since - as must be assumed in the nontheistic justification of freedom - human reason itself is a work of nature, in man there is a self-liberation of nature. This process of self-liberation will continue, in Marxian terms, until the point at which the hominization of nature and the concomitant naturalization of man have reached their apogee, i.e., until man is completely "at home" in nature. But is it possible to be "at home" in suffering, evil, and death? Religious people do not believe in such feeling "at home" because they reject the possibility of remedying the aforementioned "disasters" without God's intervention. For is it possible to be free in finitude and multiple limitations? The process of human liberation, i.e. the process of overcoming successive human limitations, asymptotically approaches a point that will never be crossed. Thus, whoever is not satisfied with a predetermined limited freedom torn away step by step from nature, whoever desires complete freedom, that is, freedom which transcends all natural limitations (which does not mean all limitations including, for example, moral or logical ones), must turn to God and his saving act.

Marx, for example, proclaimed expressis verbis that atheism and communism are "the realization of his (from the author: man's) being, the realization of his essence as something real" 38 , and also: "Religion

38 K. Marx, Economic and Philosophic Manuscripts of 1844, In: Progress Publishers, Moscow 1959; Translated by Martin Milligan, revised by Dirk J. Struik, contained in Marx/Engels, Gesamtausgabe, Abt. 1, Bd. 3. 
swą przyrodniczą naturą - nad swymi fizycznymi ograniczeniami. A ponieważ - jak należy założyć w nieteistycznym uzasadnieniu wolności - sam rozum ludzki jest dziełem natury, w człowieku dokonuje się samowyzwolenie przyrody. Proces tego samowyzwalania będzie zaś trwał - by ująć rzecz po Marksowsku - aż do punktu, w którym hominizacja przyrody i równoczesna naturalizacja człowieka nie osiągną swego apogeum, tj. dopóki człowiek nie będzie w przyrodzie całkowicie „u siebie”. Czy można jednak być „u siebie” w cierpieniu, złu oraz śmierci? Ludzie religijni nie wierzą w takie ,zadomowienie”, gdyż odrzucają możliwość zaradzenia wspomnianym „klęskom” bez interwencji Boga. Czy można być bowiem wolnym w skończoności i rozlicznych ograniczeniach. Proces uwalniania się człowieka, tj. proces przezwyciężania kolejnych ludzkich ograniczeń asymptotycznie zbliża się do punktu, którego nigdy nie przekroczy. Tak więc ten komu nie wystarcza z góry ograniczona wolność wydzierana krok po kroku przyrodzie, kto pragnie wolności pełnej, czyli takiej, która przekracza wszelkie ograniczenia naturalne (co nie znaczy, że wszelkie ograniczenia - w tym np. moralne lub logiczne), ten musi zwrócić się do Boga i jego zbawczego czynu.

Marks np. głosił expressis verbis, że to ateizm oraz komunizm są „realizacją jego (człowieka - M.Ł.) istoty, realizacją jego istoty jako czegoś rzeczywistego" ${ }^{38}$, a także: „Religia jest jedynie urojonym słońcem, które dopóty obraca się dookoła człowieka, dopóki człowiek nie obraca się dookoła samego siebie"39. Jeśli zaś Marks mówi o istocie człowieka, to chodzi mu właśnie o szeroko pojętą wolność. Niektórzy nawet wprost nazywają Marksa „filozofem wolności”40. Oczywiście można (i należy) się spierać o to, na ile marksowskie

38 K. Marks, Rękopisy ekonomiczno-filozoficzne z 1844 r., W: K. Marks, F. Engels, Dzieła, t. 1., Warszawa 1962.

39 Tamże.

40 Jak pisze abp Reinhard Marx: „Ale skrzywdzilibyśmy Karola Marksa, gdybyśmy zaprzeczyli, że także jemu chodzi o urzeczywistnienie wolności. Pod tym względem Marks jest myślicielem typowo nowożytnym, stojącym na gruncie oświeceniowej filozofii wolności. Marks nie zamierzał anulować wolnościowego programu naszych czasów, lecz właśnie go ściśle wypełnić” (Abp Reinhard Marx 
is only an imaginary sun, which continues to revolve around man until man revolves around himself" 39 . And if Marx speaks of the essence of man, it is freedom in its broadest sense. Some even explicitly call Marx the "philosopher of freedom." ${ }^{40}$ Clearly, one can (and should) argue about the extent to which the Marxian understanding of freedom is correct (i.e. has a humanist character favourable to man), and to what extent it bears the seeds or stigma of totalitarian enslavement (i.e. it is something "inhuman"). ${ }^{41}$ Here, however, the author stresses only that for this thinker, religion with its central image, God, constitutes a diminution (if not a deprivation) of human freedom. Besides, Marx expresses this explicitly by writing: "The criticism of religion ends with the teaching that man is the highest essence for man - hence, with the categoric imperative to overthrow all relations in which man is a debased, enslaved, abandoned, despicable essence, [...]." ${ }^{92}$ The completely erroneous Marxian conviction that, behold, religion will disappear with the change of the social situation, which "cannot do without illusions," must be contrasted with Paul Tillich's opinion: "Religion [in this sense] (as turning towards and being grasped by the Unconditioned - clarifies the author of the paper) lasts as long as

39 Ibid.

40 As Archbishop Reinhard Marx writes: „But we would be doing Karl Marx a disservice if we denied that he too was concerned with the realization of freedom. In this respect, Marx is a typically modern thinker, standing on the ground of the Enlightenment philosophy of freedom. Marx did not intend to cancel the libertarian program of our time, but actually to fulfill it thoroughly" (Archbishop Reinhard Marx (in collaboration with Dr. Arnd Küppers), Das Kapital: A Plea for Man, transl. Janusz Serafin CSsR, Homo Dei, Cracow 2009, p. 47).

${ }^{41}$ The author discusses it, among others, in the article Marks i idea końca religijności [Eng.: Marx and the Idea of the End of Religiosity] - „Przegląd Filozoficzny - Nowa Seria” [„Philosophical Review - New Series”] R. 27: 2018, No. 4 (108), Warsaw 2018, pp. 235-255.

${ }^{42}$ K. Marx, Contributions to the Critique of Hegel's 'Philosophy of Right'. Introduction, in: K. Marx, F. Engels, Collected Works vol. 1, Oxford University Press, 1970, Translated: Joseph O’Malley.

Nevertheless, numerous human misfortunes and tragedies were connected precisely with the ideological conviction that man is a "supreme being". 
rozumienie wolności jest słuszne (tj. mające sprzyjający człowiekowi, humanistyczny charakter), a na ile nosi ono w sobie zalążki czy piętno totalitarnego zniewolenia (czyli jest czymś „nieludzkim”) ${ }^{41}$. Tutaj jednak podkreślam tylko, że dla tego myśliciela religia wraz z jej głównym wyobrażeniem, jakim jest Bóg, stanowi umniejszenie (jeśli w ogóle nie pozbawienie) ludzkiej wolności. Zresztą Marks wyraża to wprost pisząc: „Krytyka religii kończy się tezą, że człowiek jest istota najwyższa dla czlowieka, a więc kończy się kategorycznym nakazem obalenia wszelkich stosunków, w których człowiek jest istotą poniżoną, ujarzmioną, opuszczoną i godną pogardy [...]"42. Zupełnie błędnemu Marksowskiemu przeświadczeniu, że oto religia zniknie wraz ze zmianą sytuacji społecznej, która „bez złudzeń obejść się nie może”, należy przeciwstawić opinię Paula Tillicha: „Religia w tym znaczeniu (jako skierowanie się ku i bycie pochwyconym przez Nieuwarunkowane - M. Ł.) żyje dopóty, dopóki żyje człowiek; nie może zniknąć z ludzkiej historii, bowiem historia bez religii nie byłaby już historią ludzką"43.

Za Iris Mudroch zauważmy jeszcze, że wszystkie te koncepcje moralne, których systemy wartości nie są ugruntowywane w rzeczywistości transcendentnej - w Bogu - jako centralną swą kategorię (jako „nadrzędne pojęcie moralne”) ustanawiają wolność (odwagę, wolę, moc, czyn). To ludzka wolność bez Boga ma sama z siebie ustanawiać świat ludzkich wartości ${ }^{44}$. Tylko pojawia się pytanie podstawowe: jak jest ona możliwa w ramach tego świata? Przecież wybory ludzkie

(we współpracy z dr.Arndem Küppersem), Kapitał. Mowa w obronie człowieka, tłum. Janusz Serafin CSsR, Homo Dei, Kraków 2009, s. 47).

${ }^{41}$ Piszę o tym m. in. w artykule Marks i idea końca religijności, - „Przegląd Filozoficzny - Nowa Seria” R. 27: 2018, Nr 4 (108), Warszawa 2018, s. 235-255.

${ }^{42}$ K. Marks, Przyczynek do krytyki Heglowskiej filozofii prawa. Wstęp, w: K. Marka, F. Engels, Dzieła t. 1., Warszawa 1962, s. 466. Ileż to jednak ludzkich nieszczęść i tragedii wiązało się właśnie z ideologicznym przeświadczeniem, że człowiek jest ,,istotą najwyższą".

43 P. Tillich, Pytanie o Nieuwarunkowane, tłum. Juliusz Zychowicz (przedm. Krzysztof Mech), Wydawnictwo Znak, Kraków 1994, s. 319.

${ }^{44}$ Iris Mudroch, Prymat dobra, Wydawnictwo Znak, Kraków 1996, s. 102-103. 
man lasts. It cannot disappear in human history, because a history without religion is no longer human history." ${ }^{43}$

Following Iris Mudroch, it should also be noted that all those moral concepts whose value systems are not grounded in a transcendent reality - in God - establish freedom (courage, will, power, action) as their central category (as the "supreme moral concept"). It is human freedom without God which, of itself, has to establish the world of human values ${ }^{44}$. Only the fundamental question arises: how is it possible in this world? After all, man's choices will always be determined by his natural nature and, in that sense, will never be free. Is man by himself capable of transcending his own very selfish nature? The Christian perspective is skeptical about this, especially in the eschatological dimension. Man errs by nature; therefore, the ultimate triumph of goodness cannot be due to man alone. Without Christ's salvific deed, in spite of the best intentions and ideals to reform social life and in spite of the partial successes in this matter, the curse of recurring evil would always hang over human history.

Some atheists find it difficult to understand how human freedom can harmonize with the religious postulate of obedience to God. However, as Guardini points out, "[...] obedience to God is not submission to violence, but simply the only possibility of doing what is right and proper"45. The theologian argues that obedience to God cannot be understood in the same way as obedience to another person. For when it comes to obedience to God, it is not the case that "[...] when I obey that person, I obey not myself but someone." ${ }^{946}$ It is not so, because God, though he is not me, "[...] is wherein my entire existence, my entire truth about myself, my entire sense of myself, is grounded. ${ }^{.47}$ Reference to God as the source gives man the possibility

${ }^{43}$ P. Tillich, The Question of the Unconditioned, transl. Juliusz Zychowicz (foreword by Krzysztof Mech), Znak Publishing House, Cracow 1994, p. 319.

${ }^{44}$ Iris Mudroch, The Sovereignty of Good, Znak Publishing House, Cracow 1996, pp. 102-103.

45 R. Guardini, Freedom, Grace, and Destiny, p. 90.

46 Ibid.

47 Ibid. 
zawsze będą determinowane jego przyrodniczą naturą - i w tym sensie nie będą nigdy wolne. Czy człowiek sam z siebie jest w stanie wyjść poza własną bardzo egoistyczną naturę? Perspektywa chrześcijańska jest w tym wypadku sceptyczna - szczególnie w wymiarze eschatologicznym. Człowiek błądzi z natury; dlatego ostateczny triumf dobra nie może być tylko jego zasługą. Bez zbawczego czynu Chrystusa - mimo najlepszych chęci i ideałów reformowania życia społecznego oraz mimo cząstkowych sukcesów w tej materii - nad dziejami ludzkimi zawsze ciążyłoby przekleństwo powracającego zła.

Niektórym ateistom trudno jest zrozumieć, jak ludzka wolność może harmonizować z religijnym postulatem posłuszeństwa wobec Boga. Jednakże - jak wskazuje Guardini - „,...] posłuszeństwo względem Boga nie jest podporządkowaniem się przemocy, lecz po prostu jedyną możliwością uczynienia tego, co słuszne i właściwe"45. Teolog argumentuje przy tym, że posłuszeństwo wobec Boga nie może być rozumiane tak, jak posłuszeństwo wobec innego człowieka. W przypadku posłuszeństwa przed Bogiem nie jest bowiem tak, że ,[...] gdy jestem posłuszny temu komuś, jestem posłuszny nie sobie, lecz komus'”46. Nie jest tak, ponieważ Bóg - chociaż nie jest mną „[...] jest tym, w czym ugruntowana jest cała moja egzystencja, cała prawda o mnie samym, cały sens mnie samego"47. Odniesienie do Boga jako źródła daje człowiekowi możliwość życia w prawdzie o sobie samym, zrealizowania swej najgłębszej człowieczej istoty, której niezbywalnym elementem jest wolność sama-mianowicie wolność do dobra. Wolność, której horyzontu nie stanowi dobro, jest wolnością fałszywą, czyli zupełną samowolą. U Balthasara czytamy z kolei: „Wolności skończonej została dana miara (metron) utożsamiająca się z postulatem posłuszeństwa wobec Wolności Nieskończonej, która w sobie samej i dla stworzeń jest kwintesencją Dobra"48.

\footnotetext{
45 R. Guardini, Wolność-łaska-los, s. 90.

46 Tamże.

47 Tamże.

${ }^{48}$ H.U. von Balthasar, Teodramatyka 2., cz. 1., s. 134.
} 
of living in the truth about himself, of realizing his deepest human being, the inalienable element of which is freedom itself - namely, freedom for the good. Any freedom which does not have the good as its horizon is a false freedom, that is to say, it is utterly selfwilled. On the other hand, Balthasar writes: "Finite freedom has been given a measure (metron) identifying itself with the postulate of obedience to Infinite Freedom, which in itself and for creatures is the quintessence of the Good." 48

However, an atheist might reason like this: What does obedience to God mean in practice, if not obedience to the kerygma of Scripture and the precepts of the catechism? And if so, is it not obedience to the precepts of religious sages and priests? The heteronomy of the will of the obedient would be evident in the latter case - another person tells me how to act. Another atheist might respond: it is true that there is no God and it is also true that the commandments were written by men. However, in the case of the Christian religion (in general, there could be a reference to another religion - although in this case our atheist-adversary could protest) we deal with a true message - in the sense that it goes to the essence of human needs and correctly interprets the nature of man. This would be a not infrequent case of "Christian atheism" ("an non-believing Christian").

Since ancient times, philosophers (such as Epicurus) have urged that man be freed from the fear of Gods. God as a limit on human freedom, however, can be viewed from the perspective of religion itself. For example, it may be argued that from the point of view of the doctrine of predestination, man loses an essential part of his freedom, since by the will and effort of his life he cannot change God's original determination of his salvation or damnation. ${ }^{49}$ However, the matter is not so simple here. Predestination may result from God's

${ }^{48}$ H.U. von Balthasar, Theo-Drama 2, vol. 1, p. 134.

49 As Schelling writes: „The greatest problem for the science of freedom has always been the relation of the assumed randomness of human actions to the pre-planned unity of the whole world in the divine mind. (F. W.J. Schelling, Philosophical Investigations..., p. 93. 
Ateista może jednak rozumować tak: do czego praktycznie sprowadza się posłuszeństwo Bogu, jeżeli nie do przestrzegania kerygmatów Pisma oraz nakazów katechizmu? Jeśli zaś właśnie do tego, to czyż nie jest to posłuszeństwo wobec zaleceń mędrców religijnych oraz kapłanów? Heteronomiczność woli posłusznego byłaby w tym ostatnim przypadku ewidentna - inny człowiek mówi mi jak mam postępować. Na to inny ateista mógłby mu odpowiedzieć tak: to prawda, że nie ma Boga i prawdą jest też, że przykazania ułożyli ludzie. Jednakże w przypadku religii chrześcijańskiej (ogólnie biorąc, mogłoby tu paść odniesienie do innej religii - choć w tym wypadku nasz ateista-adwersarz mógłby zaprotestować) mamy do czynienia z przesłaniem prawdziwym - w takim sensie, że trafiającym w istotę ludzkich potrzeb i właściwie odczytującym naturę człowieka. Byłby to - wcale nierzadki - przypadek ,ateizmu chrześcijańskiego” („,niewierzącego chrześcijanina").

Filozofowie już od starożytności namawiali (jak np. Epikur) do uwolnienia się człowieka od strachu przed Bogami. Na Boga jako na ograniczenie ludzkiej wolności można jednak spoglądać z perspektywy samej religii. Na przykład można uważać, że z punktu widzenia doktryny predestynacji człowiek traci zasadniczą część swojej wolności, gdyż wolą i wysiłkiem swojego życia nie może zmienić pierwotnego postanowienia Boga o jego zbawieniu albo potępieniu ${ }^{49}$. Sprawa jednak nie jest tu taka prosta. Predestynacja może bowiem wynikać z przedwiedzy Boga o przyszłych wypadkach przygodnych, tj. takich które mogłyby nie zajść, gdyby człowiek w swej wolności postąpił inaczej. Bóg z góry wie, co wybierze człowiek, lecz temu ostatniemu ta przedwiedza nie ujmuje wolności ${ }^{50}$. W związku z tym wypada zgodzić się z Heglem, który o łasce Bożej pisze tak: „Tak

49 Jak pisze Schelling: „Największym problemem dla nauki o wolności był zawsze stosunek zakładanej przypadkowości ludzkich działań do zaplanowanej wcześniej w boskim umyśle jedności całokształtu świata (F. W.J. Schelling, Filozoficzne badania ..., s. 93.

${ }^{50}$ Jak o Opatrzności pisze Kierkegaard: „[...] w swojej przedwiedzy, może wiedzieć o tym, że coś się zdarzy, chociaż ludzie ponoszą winę za to, że się dzieje [...]" (S. Kierkegaard, Wprawki do chrześcijaństwa, s. 180). 
foreknowledge of future adventitious events, i.e. events which might not have happened if man had acted differently in his freedom. God knows in advance what man will choose, but this foreknowledge does not deprive the latter of his freedom. ${ }^{50}$ Thus one must agree with Hegel, who writes of God's grace as follows: "Thus, in the case of the action of grace, man does not stand like a boulder; practically speaking, it does not act by itself, for then man would be passive material, having no part in it. Instead, it is that the purpose, the divine one, is to come into being in me through me [...]."51 And according to Schelling: „The fact that at Judas became a traitor to Christ could not be changed by Judas himself or by any creature, and yet he betrayed Christ not under compulsion, but of his own free will and full freedom." 52 However, this statement seems to be imprecise in its modal aspect. Judas could have changed his ways and not become a traitor (after all, that was his freedom and the resulting guilt), but God knew in advance how Judas would actually act in his freedom, and he did not want to change that; otherwise he would have taken away Judas' freedom. In other words, God's foreknowledge of future events is in no way the cause of the movements of finite temporal freedom - human desires and actions. Otherwise, the events that flow from these movements would not be contingent, but necessary.

The problem of predestination can also be seen in a broader and more general context, i.e. in the context of the question of the creature's dependence on God in general. Can the creature - in view of the fact that it comes from an absolute and omnipotent source - retain any autonomy with respect to him? Well, commenting on the teaching of St. Thomas, Chenu points out that "At the very heart of creation, of this radical dependence which attaches to every finite being, true

${ }^{50}$ As Kierkegaard writes of providence, ,[...] in its foreknowledge, it can know that something will happen, although people are to blame for it happening [...]" (S. Kierkegaard, An Introduction, p. 180).

${ }_{51}$ G.W. F. Hegel, Lectures (I), p. 226.

${ }^{52}$ F.W. J. Schelling, Philosophical Investigations..., p. 92. 
więc w przypadku działania łaski człowiek nie stoi jak głaz; praktycznie biorąc, nie działa ona sama, bo wówczas człowiek byłby biernym materiałem, nie mającym w tym żadnego udziału. Jest raczej tak, że cel, to, co boskie, ma we mnie powstawać dzięki mnie [...]”51. U Schellinga zaś czytamy co następuje: „Tego, że Judasz stał się zdrajcą Chrystusa, nie mógł zmienić ani sam Judasz, ani żadne stworzenie, a jednak zdradził on Chrystusa nie pod przymusem, lecz z własnej woli i w pełni wolności"52. Przy czym stwierdzenie to zdaje się być nieprecyzyjne w aspekcie modalnym. Raczej trzeba przyjąć, że Judasz mógł zmienić swoje postępowanie i nie zostać zdrajcą (na tym polega przecież jego wolność i wynikająca z niej wina), lecz Bóg z góry wiedział, jak Judasz w rzeczywistości postąpi w swej wolności, i nie chciał tego zmieniać - w przeciwnym razie odebrałby Judaszowi wolność. Inaczej mówiąc: przedwiedza Boga o przyszłych wypadkach przygodnych w żaden sposób nie jest przyczyną poruszeń skończonej wolności doczesnej - chceń i czynów ludzkich. W przeciwnym razie wypływające $z$ tych poruszeń wypadki nie byłyby przygodne, lecz konieczne.

Problem predestynacji można też widzieć w szerszym i ogólniejszym kontekście - w kontekście zagadnienia zależności stworzenia w ogóle od Boga. Czy stworzenie - wobec tego, że pochodzi za absolutnego i wszechmocnego źródła - może zachowywać jakąkolwiek wobec niego autonomię? Otóż - komentująca nauczanie św. Tomasza - Chenu zwraca uwagę, że „W samym sercu stworzenia, tej radykalnej zależności, która wiąże się z każdym bytem skończonym, będą działać prawdziwe autonomie”"53. „Rządy”, jaki Bóg sprawuje nad światem, opierają się na udzielonych stworzonym przez Niego bytom naturach (prawidłowościach). Byty te działają zatem na zasadzie tych własnych natur - i to jest ich względna i stopniowalna

${ }^{51}$ G.W. F. Hegel, Wykłady (I), s. 226.

52 F.W. J. Schelling, Filozoficzne badania ..., s. 92.

53 Marie-Dominique Chenu, Święty Tomasz z Akwinu i teologia, tłum. Arkadiusz Ziernicki, Wiesław Szymona, Wydawnictwo Znak, Kraków 1997, s. 117. 
autonomies will operate." 53 God's "ruling" over the world is based on the natures (regularities) given to the entities created by Him. These entities therefore act on the basis of these own natures, and this is their relative and gradable autonomy. It reaches its highest level in rational creatures ${ }^{54}$. Therefore, not only does God not want an "unfree" (deprived of all self-generated power) man, but also grants ontic weight and dignity to lower beings, endowing them with self-determination and a kind of perfection which is derivative from him and therefore relative.

\section{THE PRICE OF FREEDOM}

Activity in the realisation of one's own freedom by man (after all, this is the only way freedom is possible; passive, imposed freedom is contraditio in adjecto) has its price. This price is evil. Hegel understands the matter in such a way that, behold, man in himself according to his conception (internally) - is good. ${ }^{55}$ Unlike nature, however, which is only in itself, and its "in itself" is governed by the laws to which it always remains faithful, man as spirit is (must be) directed to be also for himself. To be such, however, he must be able to transgress his own nature: "[...] to be a spirit means precisely not to be something natural and immediate; but as a spirit, man is a bringing out of naturalness, a passing into that separation of his concept and his immediate existence (Dasein). ${ }^{.56}$ That possibility - not found in nature at all - of the individual separating himself from his law, from his "substantial being" constitutes freedom. But for man to be able to free himself from his own (let us remember good) nature is itself already contained in his naturalness. ${ }^{57}$ Hence,

53 Marie-Dominique Chenu, Aquinas and His Role in Theology, transl. Arkadiusz Ziernicki, Wiesław Szymona, Znak Publishing House, Cracow 1997, p. 117.

${ }^{54}$ Ibid.

55 It can be understood that man as an intrinsically rational being accurately recognises the good and rationally inclines towards it.

${ }_{56}$ G.W. F. Hegel, Lectures (II), p. 266.

57 See: Ibid, p. 267. 
autonomia. Najwyższy poziom osiąga ona w stworzeniach rozumnych ${ }^{54}$. Bóg zatem nie chce nie tylko „bezwolnego” (pozbawionego wszelkiej sprawczości własnej) człowieka, lecz także i bytom niższym przyznaje ontyczną wagę i powagę, obdarzając je - pochodną wprawdzie od niego i dlatego względną - determinacją własną i swoistą doskonałością.

\section{CENA WOLNOŚCI}

Aktywność w realizowaniu własnej wolności przez człowieka (a przecież tylko tak wolność jest możliwa; wolność bierna, narzucona to contraditio in adjecto) ma swoją cenę. Ceną tą jest zło. Hegel rozumie rzecz tak, że oto człowiek sam w sobie - według swego pojęcia (wewnętrznie) - jest dobry ${ }^{55}$. W przeciwieństwie jednak do przyrody, która jest jedynie sama $w$ sobie, a to jej „samo w sobie” regulują prawa, którym pozostaje ona zawsze wierna, człowiek jako duch jest (musi być) ukierunkowany na to, aby być także sam dla siebie. Aby jednak takim być musi mieć on możliwość wykroczenia przeciwko własnej naturze: ,[...] być duchem to właśnie nie być czymś naturalnym i bezpośrednim; lecz jako duch człowiek jest wydobywaniem się z naturalności, przechodzeniem w to oddzielenie swojego pojęcia i swojego bezpośredniego istnienia (Dasein)" ${ }^{\prime 56}$. Ta - w ogóle nie występująca w naturze - możliwość oddzielenia się indywiduum od swojego prawa, od swojej „substancjalnej istoty” jest właśnie wolnością. Jednak to wydobywanie się człowieka ze swojej własnej (przypomnijmy - dobrej) natury samo jest już zawarte w jego naturalności ${ }^{57}$. Stąd paradoksalnie (względem wyjściowej tezy) uznaje Hegel: ,człowiek jest z natury zły, jego byt sam w sobie, jego

54 Tamże.

55 Można to rozumieć tak, że - jako istota z natury rozumna - człowiek trafnie rozpoznaje dobro i rozumowo ku niemu się skłania.

56 G.W. F. Hegel, Wykłady (II), s. 266.

57 Patrz: tamże, s. 267. 
paradoxically (in relation to the initial thesis) Hegel recognizes: "man is intrinsically evil, his being in itself, his natural being is evil." ${ }^{58}$ The philosopher further explains: "A natural man is a man who in himself, according to his conception, is good; but natural in a particular sense he is as a man who follows his passions and urges, who is controlled by desire [...] and since the content of his desire is only an urge, an inclination, he is evil. According to the form [according to the fact that] he is a will, he is no longer an animal; but the content, the aims of his desire are still what is natural." 59

Hegel's standpoint outlined above discloses the ambiguity of the term "by nature": 1) according to concept (form), i.e. possibility (relatively purely formal actuality), 2) according to natural inclinations (drives, desires), i.e. according to actual natural content. From the paradoxical nature - if we can speak of such a paradox at all in this case - of Hegel's findings on the good/evil nature of man, we can also draw the conclusion that these two moments are inseparably intertwined in man, and therefore that evil is a necessary moment of his free existence. Developing the problem of the genesis of evil in a biblical spirit, Hegel states that cognition (knowledge, consciousness) is the source of evil (man ate the fruit from the Tree of Knowledge), since it is an act that brings out the negative element: cognition is separation, pra-division (Urteil, German: judgement). Therefore, the following conclusion can be drawn: since it is impossible to be a free spirit without having at one's disposal a certain amount of knowledge - and in particular, self-knowledge - evil belongs to man by nature.

However, pointing to cognition (knowledge) as a premise of evil is problematic. After all, God himself is a spirit and has knowledge. Does evil therefore belong to his nature? Theology, as a matter of fact, cannot accept such a conclusion. What can be done in this case? Well, we can say that the source of evil is only imperfect and limited human cognition. The absolute self-knowledge of God, on the other hand,

\footnotetext{
58 Ibid.

59 Ibid.
} 
byt naturalny jest złem”58. Dalej zaś filozof wyjaśnia: „Człowiekiem naturalnym jest człowiek, który sam w sobie, zgodnie ze swym pojęciem jest dobry; ale naturalny w konkretnym sensie jest on jako człowiek, który idzie za swymi namiętnościami i popędami, który jest opanowany pożądaniem [...] a skoro treścią jego chcenia jest tylko popęd, skłonność, to jest zły. Stosownie do formy [stosownie do tego,] że jest wolą, nie jest już zwierzęciem; ale treść, cele jego chcenia są jeszcze tym, co naturalne" 59 .

W zarysowanym wyżej stanowisku Hegla ujawnia się dwuznaczność terminu ,z natury”: 1) według pojęcia (formy), czyli możliwość (względnie czysto formalna aktualność), 2) według naturalnych skłonności (popędów, pożądań), czyli według faktycznej przyrodniczej treści. Z paradoksalności - jeśli w ogóle o takiej można w tym wypadku mówić - ustaleń Heglowskich na temat dobrej/złej natury człowieka można wywieść i taki wniosek, że oba te momenty przenikają się w człowieku nierozerwalnie, a zatem, że zło jest koniecznym momentem jego wolnej egzystencji. Rozwijając w biblijnym duchu problem genezy zła Hegel stwierdza, iż poznanie (wiedza, świadomość) jest źródłem zła (człowiek zjadł owoc z Drzewa Poznania), gdyż jest to akt, w którym dochodzi do wyeksponowania pierwiastka negatywnego: poznawanie jest rozdzielaniem, pra-podziałem (Urteil, niem. sąd). Z powyższego można wyprowadzić następujący wniosek: ponieważ nie można być wolnym duchem nie dysponując w pewnym zakresie wiedzą - a w szczególności samowiedzą - zło przynależy człowiekowi z natury.

Ze wskazaniem poznania (wiedzy) jako przesłanki zła jest jednak pewien problem. Wszak sam Bóg jest duchem i ma wiedzę. Czyżby w związku z tym zło należało do jego natury? Na taki wniosek teologia nie może sobie przecież pozwolić. Co można w tym wypadku zrobić? Otóż można stwierdzić, że źródłem zła jest tylko niedoskonałe i ograniczone poznanie ludzkie. Absolutna samowiedza Boga nie wprowadza zaś żadnego podziału, nie wyprowadza poza Boga

\footnotetext{
58 Tamże.

59 Tamże.
} 
does not introduce any division, does not lead beyond God himself, since it embraces everything in the identical sameness $A=A^{60}$. And here the dialectically positive side of cognition is revealed - after all, it strives for Truth. And although in this pursuit it is originally a "malignant" primeval division, what it strives for (should strive for) is truthfulness understood as "reconciliation" and equalization (or at least restoration of the greatest possible similarity). According to Hegel, in this pursuit man achieves immortality ${ }^{61}$. In other words: after the original division, knowledge should lead to the knowledge of the unity of being as such, or theistically speaking: the unity of God and the created world. One could put it this way: the doer of evil ("original-divider") in fact has an intuition of good and longs for it. If this were not so, it would be difficult to say that he is evil. It would only be something like a destructive element - the powers of nature (including animals) are not evil. As Hegel writes: "If in the subject itself there is not in its innermost being also a consciousness of the good, an infinite demand for the good, then there is no pain in it, then evil itself is only an empty Nothing - evil exists only in this contradiction." ${ }^{62}$

\section{THE SOCIAL ASPECT OF FREEDOM}

Approaching the end of the discussion on human freedom, the author points out one more dimension of being free - the social one. In the Christian perspective, God not only gives man individual freedom of choice, but also clearly indicates the indispensability of social freedom (freedom of some people in relation to others), which results from the fact that before God all are both free and equal. This is why Hegel, who calls this indication "the principle of absolute

${ }^{60}$ As with Leibniz (Gottfried. Wilhelm. Leibniz): knowledge from the Divine perspective is purely analytical and results from such primordial sameness.

${ }^{61}$ Cf: G.W. F. Hegel, Lectures (II), p. 272-277.

${ }^{62}$ Ibid, p. 279. 
samego, gdyż obejmuje wszystko w równej samej sobie identyczności $A=A^{60}$. I tu ujawnia się dialektycznie pozytywna strona poznania wszak dąży ono przecież do Prawdy. I chociaż w tym swym dążeniu jest pierwotnie ,złogennym” prapodziałem, tym, do czego ono dąży (dążyć powinno), jest prawdziwość rozumiana jako „pojednanie” i zrównanie (a w każdym razie przywrócenie jak największego podobieństwa). Zdaniem Hegla w tym swoim dążeniu człowiek osiąga nieśmiertelnośśćl. Inaczej mówiąc: po pierwotnym podzieleniu wiedza powinna dochodzić do poznania jedności bytu jako takiego, a mówiąc teistycznie: jedności Boga i świata stworzonego. Rzecz można ująć tak: czyniący zło (,pra-dzielący”) w gruncie rzeczy ma intuicję dobra i tęskni za nim. Jeśli by tak nie było, to trudno by mówić, iż jest on zły. Byłby jedynie czymś w rodzaju niszczącego żywiołu - moce natury (w tym zwierzęta) nie są złe. Jak pisze Hegel: „Jeśli w samym podmiocie nie ma w jego najbardziej wewnętrznej istocie również świadomości dobra, nieskończonego żądania dobra, to nie ma w nim żadnego bólu, to samo zło jest tylko pustym Niczym - zło istnieje tylko w tym przeciwieństwie" ${ }^{62}$.

\section{SPOLECZNY ASPEKT WOLNOŚCI}

Zbliżając się do końca rozważań o ludzkiej wolności, chciałbym wskazać jeszcze jeden wymiar bycia wolnym - wymiar społeczny. W perspektywie chrześcijańskiej Bóg daje człowiekowi nie tylko indywidualną wolność wyboru, lecz wyraźnie wskazuje na nieodzowność wolności społecznej (wolność jednych ludzi wobec drugich), która wynika z faktu, że wobec Boga wszyscy są zarówno wolni i równi. Dlatego też Hegel, który wskazanie to nazywa ,zasadą absolutnej wolności w Bogu"63, właśnie religię chrześcijańską postrzegał

${ }^{60}$ Jak u Leibniza (Gottfried. Wilhelm. Leibniz): wiedza z Boskiej perspektywy ma charakter czysto analityczny i wynika z takiej pierwotnej identyczności.

${ }^{61}$ Porównaj: G.W. F. Hegel, Wykłady (II), s. 272-277.

62 Tamże, s. 279.

63 Podaję to za: W. Pannenberg, Człowiek, wolność, Bóg, s. 95. 
freedom in God"63, perceived the Christian religion precisely as the one which enables the realisation of the true principle of the state. For Hegel, this principle is based on subjective freedom and on the subjectivity of the ethical disposition ${ }^{64}$. This should be understood as a demand that free individuals in civil society should regard morality as something of their own and not imposed from outside; that they should voluntarily - and not by any form of coercion or enslavement - participate in a universal ethicality. For Hegel, the true ethicality that should prevail in the state is a corollary of religion, and the social and state functionality of the latter is based on the fact that it "has absolute truth for its content." ${ }^{65}$ In this context, Hegel places particular emphasis on the connection between the history of freedom and the dogma of the incarnation ${ }^{66}$. God's descent into the world brings freedom to mankind, for Christ is incarnated as man, not as a representative of a particular race or nation. Although he belongs to the Jewish people, in the context of the whole New Testament message he must be regarded as the "universal man", representing all people, taking upon himself the sins of all and bringing redemption to all.

\section{FREEDOM TO DO GOOD. CONCLUSIONS}

While writing about human freedom up to now, the author has basically had one form of freedom in mind: freedom understood as the freedom to choose between good and evil, as the possibility of being subject to "self-determination", that is to say, not imposed from above by God, nature or society. To conclude this article, the notion of freedom will be somewhat systematised by distinguishing three of its forms. In fact, it must be acknowledged that alongside the above-mentioned "freedom from" (from external determination),

\footnotetext{
63 Cited after: W. Pannenberg, The Idea of God and Human Freedom, p. 95.

${ }^{64}$ Ibid, pp. 94-95.

65 Ibid, p. 94

66 Ibid, pp. 95-96.
} 
jako umożliwiającą realizację prawdziwej zasady państwa. Zasada ta opiera się bowiem dla Hegla na wolności subiektywnej i na subiektywności usposobienia etycznego ${ }^{64}$. Należy to rozumieć jako postulat, aby wolne jednostki w społeczeństwie obywatelskim moralność traktowały jako coś własnego, a nie narzuconego z zewnątrz; aby dobrowolnie - a nie na zasadzie jakiejkolwiek formy przymusu czy zniewolenia - uczestniczyły w powszechnej etyczności. Dla Hegla prawdziwa etyczność, która powinna panować w państwie, jest następstwem religii, a funkcjonalność społeczna i państwowa tej ostatniej opiera się na tym, iż „ma ona prawdę absolutną za swą treść" 65 . W tym kontekście szczególny nacisk kładzie Hegel na powiązanie dziejów wolności z dogmatem o wcieleniu ${ }^{66}$. Zstąpienie Boga w świat przynosi ludziom wolność, gdyż Chrystus wcielił się w człowieka jako człowieka, a nie człowieka jako przedstawiciela określonej rasy czy narodu. Wprawdzie należy On do narodu żydowskiego; jednak w kontekście całego przekazu nowotestamentowego trzeba Go traktować jako „człowieka uniwersalnego” - w tym sensie że reprezentuje on wszystkich ludzi - grzechy wszystkich bierze na siebie i wszystkim niesie odkupienie.

\section{WOLNOŚĆ DO DOBRA. ZAKOŃCZENIE}

Pisząc do tej pory o wolności człowieka, miałem w zasadzie na uwadze jedną jej postać: wolność rozumianą jako swobodę wyboru między dobrem a złem, jako możliwość podlegania „determinacji własnej”, a więc nie narzuconej z góry przez Boga, przyrodę czy społeczeństwo. Kończąc ten artykuł usystematyzuję nieco pojęcie wolności wyróżniając trzy jej formy. Trzeba bowiem uznać, że obok wspomnianej wyżej „wolności od” (od determinacji zewnętrznej), koniecznym jej uzupełnieniem - przynajmniej z chrześcijańskiego

\footnotetext{
64 Tamże, s. 94-95.

65 Tamże, s. 94

66 Tamże, s. 95-96.
} 
its necessary complement - at least from the Christian point of view is the "freedom for"-the freedom for good ${ }^{67}$. It is understood not only in terms of the fact that one can always choose the good (the first case), but that only the choice of the good makes a person truly free. As Balthasar writes after Anselm: [...] only the one who loves the good for its own sake is free." ${ }^{\prime 6}$ The "free" act of choosing evil is only seemingly free, for behind evil lurks a compulsion of nature - a selfish drive. There is, however, another form of "freedom from" which is perhaps the highest degree of freedom - freedom as independence from temporality. It is expressed in St. Paul's words: "What I mean, brothers and sisters, is that the time is short. From now on those who have wives should live as if they do not; 30 those who mourn, as if they did not; those who are happy, as if they were not; those who buy something, as if it were not theirs to keep; 31 those who use the things of the world, as if not engrossed in them. For this world in its present form is passing away." (Corinthians 7:29-32) ${ }^{69}$. In principle, this freedom can be defined as independence from time, as an - already taking place in real time - "immersion" in eternity, as living in its perspective. Such freedom draws from us all existential dread and defeats evil. For where there is nothing to fear, there is also no fear of anything and evil loses its main motive. However, and this must be emphasized, for a Christian this freedom does not mean the negation or crossing out of natural reality and the life taking place within it. Life must be lived here and now. There is only a change of emphasis: the perspective of the Ultimate, of living in the eschaton of eternity.

Freedom as independence from temporality cannot be just an empty distancing from the world and life, a kind of stoic apatheia, a dead indifference "to everything", an existential collapse. In the Christian

67 „Freedom to” is superior to „freedom from”. For freeing ourselves from something only makes sense when we strive for something else - something higher, better, of more value.

${ }^{68}$ H.U. von Balthasar, Theo-Drama 2, vol. 1, p. 214

69 The Holy Scriptures https://www.biblegateway.com/passage/?search=1\%20 Corinthians $\% 207 \% 3$ A29-32\&version=NIV 
punktu widzenia - jest „,wolność do"- wolność do dobra ${ }^{67}$. Rozumiana nie tylko tak, że zawsze mogę wybrać dobro (przypadek pierwszy), lecz że tylko wybór dobra czyni mnie prawdziwie wolnym. Jak za Anzelmem pisze Balthasar: [...] wolny jest tylko ten, kto kocha dobro ze względu na nie samo"68. „Wolny” akt wyboru zła jest tylko pozornie wolny, gdyż za złem czai się przymus natury - egoistyczny pęd. Jest wszak jeszcze jedna postać „wolności od”, która jest bodaj najwyższym stopniem wolności - wolność jako niezależność od doczesności. Wyraża ją następujący postulat św. Pawła: „Mówię, bracia, czas jest krótki. Trzeba więc, aby ci, którzy mają żony, tak żyli, jakby byli nieżonaci, , a ci , którzy płaczą, tak jakby nie płakali, ci zaś, co się radują, tak jakby się nie radowali; ci którzy nabywają, jak gdyby nie posiadali; ci, którzy używają tego świata, tak jakby z niego nie korzystali. Przemija bowiem postać tego świata (Kor, 7, 29-32)"'69. W zasadzie wolność ta może być określona jako niezależność od czasu; jako - już teraz w realnym czasie mające miejsce - „zanurzenie” się w wieczności, jako życie w jej perspektywie. Wolność taka ściąga z nas wszelką egzystencjalną trwogę i pokonuje zło. Tam bowiem, gdzie nie ma się czego lękać, nie ma też strachu przed niczym i zło traci swój główny motyw. Przy czym - co należy podkreślić - wolność ta nie oznacza dla chrześcijanina negacji czy przekreślenia naturalnej rzeczywistości i toczącego się w niej życia. Żyć trzeba tu i teraz. Idzie tu tylko o zmianę akcentów - o wysunięcie się na czoło w życiu doczesnym perspektywy Ostateczności, o życie w eschatonie wieczności.

Wolność jako niezależność od doczesności nie może być tylko pustym zdystansowaniem się od świata i życia, jakąś stoicką apatheia, martwą obojętnością „na wszystko”, egzystencjalną zapaścią.

67 „Wolność do” jest nadrzędna wobec „wolności od”. Uwalnianie się bowiem od czegoś ma sens jedynie wtedy, gdy dążymy do czegoś innego - wyższego, lepszego, wartościowszego.

${ }^{68}$ H.U. von Balthasar, Teodramatyka 2., cz. 1., s. 214

${ }^{69}$ Pismo Święte Starego i Nowego Testamentu (Biblia Tysiąclecia), Wydawnictwo Pallottinum, Poznań-Warszawa 1971, s. 1297. 
sense, this distancing makes sense only as an attitude that directs us towards God. As Balthasar, following St Augustine, puts it: human finite freedom (the simple freedom to choose between good and evil) "[...] realises itself and becomes actualised freedom (libertas) only within Infinite Freedom."

Thus, true Christian freedom is not the freedom to choose between good and evil, but the freedom resulting from submission to God - the good itself. The latter has as its premise a purely formal freedom of choice - man can deny God, reject him. But there is a fundamental difference between the freedom which does not choose God but evil, and the freedom which chooses and submits to God. In the first case, man merely exercises his "formal right", while he places himself in slavery to sin. In the second case, by choosing to be subject to God, he proves to be, paradoxically, supremely free. This paradoxical situation of subordination disappears immediately when we understand that God's law should not be treated - as in the Old Testament - as something external to us: a strict God ordered one to live in a certain way, and his wrath can be terrible. No, fear of anyone - not even of God - does not give freedom. It is therefore a question of submitting to such a divine law as has been internalized by man - it is in him, since God in his grace revealed it to him and he recognized it in his mind and accepted it as his own with his free will. This law is the law of love. According to Christian theology, it is just this internalization by man of the true love of God which raises him to the highest possible level of freedom, obviously always with the decisive contribution of divine grace. To want the good and to do the good, in full trust in God's providence is true freedom.

${ }^{70}$ H.U. von Balthasar, Theo-Drama 2, vol. 1, p. 220. 
W rozumieniu chrześcijańskim to dystansowanie się ma sens tylko jako postawa nakierowująca nas na Boga. Jak - za św. Augustynem - rzecz ujmuje Balthasar: ludzka skończona wolność (prosta wolność wyboru między dobrem i złem) ,[...] realizuje się i staje się rzeczywistą wolnością zaktualizowaną (libertas) jedynie w obrębie Wolności Nieskończonej"70.

Tak więc prawdziwa wolność chrześcijańska to nie wolność wyboru nie między dobrem a złem, lecz wolność wynikająca z podporządkowania się Bogu - dobru samemu. Ta ostatnia ma za przesłankę czysto formalną wolność wyboru - człowiek może zaprzeczyć Bogu, odrzucić Go. Ale jest zasadnicza różnica między wolnością, która nie wybrała Boga, lecz zło, a wolnością, która wybiera i podporządkowuje się Bogu. W tym pierwszym przypadku człowiek korzysta jedynie z przysługującego mu „formalnego prawa”, podczas gdy oddaje się w niewolę grzechu. W drugim, wybierając podporządkowanie się Bogu, okazuje się - paradoksalnie - w najwyższym stopniu wolnym. Rzeczona paradoksalność sytuacji podporządkowania znika natychmiast, gdy zrozumiemy, że prawo Boże nie powinno być - jak ma to miejsce jeszcze w Starym Testamencie - traktowane jako coś zewnętrznego wobec nas: surowy Bóg nakazał żyć tak a tak, a gniew jego może być straszny. Nie, strach przed nikim - nawet przed Bogiem - nie daje wolności. Chodzi tu zatem o podporządkowanie się takiemu prawu Bożemu, które zostało przez człowieka uwewnętrznione - tkwi w nim, gdyż Bóg w swej łasce mu je objawił, a on je rozpoznał w swoim umysłem i przyjął jako własne swoją wolną wolą. Tym prawem jest prawo miłości. W myśl teologii chrześcijańskiej właśnie to uwewnętrznienie przez człowieka prawdziwej Bożej miłości wznosi go na najwyższy z możliwych do osiągnięcia przez niego - oczywiście zawsze przy decydującym udziale Bożej łaski poziomów wolności. Chcieć dobra i czynić dobro w pełnej ufności w opatrzność Bożą - oto wolność prawdziwa.

${ }^{70}$ H.U. von Balthasar, Teodramatyka 2., cz. 1., s. 220. 


\title{
Summary
}

Because it is very hard to find the fundations of the human freedom in a materialistic world, in this paper I am consider the human freedom from theological perspective. I base not only on classical theology but also on philosophical theology of G.W.F. Hegel and F.W. J. Schelling. I think that the theological point of view allowed me to justify the existance of freedom in deterministic world and to define its highest level.

Keywords: freedeom, determinism, God, grace, atheism, autonomy, good.

\begin{abstract}
About the Author
Professor Marek Lagosz works at the Institute of Philosophy of the University of Wrocław, where he heads the Department of Ontology and Philosophy of Nature. Up until now, he has published six books to date: „Znaczenie i prawda. Rozważania o Fregowskiej semantyce zdań" ["Meaning and Truth. Reflections on Fregowski's Semantics of Sentences”] (Wroclaw, 2000), „Brzytwa Ockhama a wykazywanie nieistnienia" ["Occam's Razor and the Demonstration of Non-Existence"] (Wroclaw, 2002), „Realność czasu” [“The Reality of Time”] (2007), ,Marks. Praca i czas. Wartość czasu w ekonomii i moralności" ["Marx. Work and Time. The Value of Time in Economics and Morality”] (Warsaw 2012), „O świadomości. Fenomenologia zjawisk umysłowych" ["On Awareness. Phenomenology of Mental Phenomena"] (Kęty 2016), „Ontologia. Materializm i jego granice” [“Ontology. Materialism and its Limits"] (Krakow 2019). Author of numerous publications in, among others, „Filozofia Nauki” ["Philosophy of Science”], „Kwartalnik Filozoficzny” ["Philosophical Quarterly”], „Przegląd Filozoficzny” ["Philosophical Review”], „Ruch Filozoficzny" ["Philosophical Movement"], "Principia", "Philosophy and Science. Philosophical and Interdisciplinary Studies", "Studia Philosophiae Christianae" and "Studia Philosophica Wratislaviensia". Interested in ontology, epistemology, analytic philosophy, Karl Marx's philosophy, and phenomenology. President of the Regional Committee of the Philosophy Contest in Wrocław.
\end{abstract}




\section{Streszczenie}

Wolność człowieka w materialnym świecie stanowi jedną z największych zagadek filozoficznych (ontologicznych): czy można ją pogodzić z deterministycznym charakterem natury ? Ponieważ zakładam (co staram się w tym artykule także uzasadnić), że odpowiedź na powyższe pytanie jest negatywna, uwagę swą kieruję ku teologicznemu uzasadnieniu wolności - włączając w tę perspektywę nie tylko teologię klasyczną, lecz także teologię filozoficzną Friedricha W.J. Schellinga oraz Georga W.F. Hegla. Dochodzę do wniosku, że teologiczny punkt widzenia nie tylko pozwala wytłumaczyć obecność wolności w deterministycznym świecie, lecz także - określić, na czym polega najwyższy jej stopień.

Słowa klucze: wolność, determinizm, Bóg, łaska, autonomia, ateizm, dobro

\section{O autorze}

Profesor Marek Łagosz pracuje w Instytucie Filozofii Uniwersytetu Wrocławskiego, gdzie kieruje Zakładem Ontologii i Filozofii Przyrody. Dotychczas opublikował sześć książek: „Znaczenie i prawda. Rozważania o Fregowskiej semantyce zdań” (Wrocław 2000), „Brzytwa Ockhama a wykazywanie nieistnienia” (Wrocław 2002), „Realność czasu” (2007), „Marks. Praca i czas. Wartość czasu w ekonomii i moralności” (Warszawa 2012), „O świadomości. Fenomenologia zjawisk umysłowych” (Kęty 2016), „Ontologia. Materializm i jego granice” (Kraków 2019) . Autor licznych publikacji m. in. w „Filozofii Nauki”, „Kwartalniku Filozoficznym”, „Przeglądzie Filozoficznym”, „Ruchu Filozoficznym”, „Principiach”, „Filozofii i nauce. Studiach filozoficznych i interdyscyplinarnych”, „Studia Philosophiae Christianae" oraz Studia Philosophica Wratislaviensia”. Interesuje się ontologią, epistemologią, filozofią analityczną, filozofią Karola Marksa oraz fenomenologią. Jest przewodniczącym Okręgowego Komitetu Olimpiady Filozoficznej we Wrocławiu

\section{Bibliografia}

Balthasar von H.U., Teodramatyka 2. Osoby dramatu, cz. 1. Człowiek w Bogu, Wydawnictwo M, Kraków 2006;

Barth K., Dogmatyka w zarysie, tłum. Ivonna Nowicka, Wydawnictwo Naukowe Semper 1994;

Chenu M.-D., Święty Tomasz z Akwinu i teologia, tłum. Arkadiusz Ziernicki,

Wiesław Szymona, Wydawnictwo Znak, Kraków 1997; 


\section{Bibliography}

Balthasar von H. U., Theo-Drama: Theological Dramatic Theory: The Dramatis Personae: Man in God, vol. 1, Ignatius Press. The Polish version has slightly modified according to the German original, M Publishing House, Cracow 2006;

Barth K., Dogmatics in Outline, transl. Ivonna Nowicka, Wydawnictwo Naukowe Semper 1994;

Chenu M.-D., Aquinas and His Role in Theology, transl. Arkadiusz Ziernicki, Wiesław Szymona, Znak Publishing House, Cracow 1997;

Ganoczy A., Stwórczy czlowiek i Bóg stwórca [The Creator Man and the Creator God], PAX Publishing Institute, Warsaw 1982;

Guardini R., Freedom, Grace, and Destiny. Three Chapters in the Interpretation of Existence, Pantheon Books, 1961; Polish edition by Znak Publishing House, Krakow 1995;

Hegel G.W. F., Lectures on the Philosophy of Religion, Vol. I, PWN Scientific Publishers, Warsaw 2006;

Hegel G.W. F., Lectures on the Philosophy of Religion, Vol. II, PWN Scientific Publishers, Warsaw 2007;

Kierkegaard S., An Introduction, transl. Antoni Szwed, ANTYK Publishing House, Kęty 2002;

Łagosz M., Marks i idea końca religijności [Marx and the Idea of the End of Religiosity], - „Przegląd Filozoficzny - Nowa Seria” ["Philosophical Review - New Series"] R. 27: 2018, Nr 4 (108), Warsaw 2018;

Marcel Gabriel, The Mystery of Being. translated by Małgorzata Frankiewicz, foreword by Karol Tarnowski, Znak Publishing House, Cracow 1995;

Marx K., Contributions to the Critique of Hegel's 'Philosophy of Right'. Introduction, in: K. Marx, F. Engels, Collected Works vol. 1, Oxford University Press, 1970, Translated: Joseph O'Malley;

K. Marx, Economic and Philosophic Manuscripts of 1844, In: Progress Publishers, Moscow 1959; Translated by Martin Milligan, revised by Dirk J. Struik, contained in Marx/Engels, Gesamtausgabe, Abt. 1, Bd. 3.;

Marx R., Das Kapital: A Plea for Man, transl. Janusz Serafin CSsR, Homo Dei, Cracow 2009;

The Holy Scriptures https://www.biblegateway.com/passage/?search $=1 \% 20$ Corinthians\%207\%3A29-32\&version=NIV;

Rahner K., The Fundations of Christian Faith: An Introduction to the Idea of Christianity, transl. Tadeusz Mieszkowski, Instytut Wydawniczy PAX, Warsaw 1987 
Ganoczy A., Stwórczy człowiek i Bóg stwórca, Instytut Wydawniczy PAX, Warszawa 1982;

Guardini R., Wolność-łaska-los. Rozważania o sensie istnienia, Wydawnictwo Znak, Kraków 1995;

Hegel G.W. F., Wykłady z filozofii religii, Tom I, Wydawnictwo Naukowe PWN, Warszawa 2006;

Hegel G.W. F., Wykłady z filozofii religii, Tom II, Wydawnictwo Naukowe PWN, Warszawa 2007;

Kierkegaard S., Wprawki do chrześcijaństwa, tłum. Antoni Szwed, Wydawnictwo ANTYK, Kęty 2002;

Łagosz M., Marks i idea końca religijności, - „Przegląd Filozoficzny - Nowa Seria” R. 27: 2018, Nr 4 (108), Warszawa 2018;

Marcel Gabriel, Tajemnica bytu, tłum. Małgorzata Frankiewicz, przedm. Karol Tarnowski, Wydawnictwo Znak, Kraków 1995;

Marks K., Przyczynek do krytyki Heglowskiejfilozofii prawa. Wstęp, w: K. Marka, F. Engels, Dzieła t. 1., Warszawa 1962;

Marks K., Rękopisy ekonomiczno-filozoficzne z 1844 r., W: K. Marks, F. Engels, Dzieła, $t$. 1., Warszawa 1962;

Marx R., Kapitał. Mowa w obronie człowieka, tłum. Janusz Serafin CSsR, Homo Dei, Kraków 2009;

Pismo Święte Starego i Nowego Testamentu (Biblia Tysiąclecia), Wydawnictwo Pallottinum, Poznań-Warszawa 1971;

Rahner K., Podstawowy wyktad wiary. Wprowadzenie do pojęcia chrześcijaństwa, tłum. Tadeusz Mieszkowski, Instytut Wydawniczy PAX, Warszawa 1987

Sarnowski S., Świadomość i czas. O początkach filozofii współczesnej, PWN, Warszawa 1985;

Schelling F.W. J., Filozoficzne badania nad istota wolności i sprawami z tym zwiazanymi, inter esse, Kraków 1990;

Tillich P., Pytanie o Nieuwarunkowane, tłum. Juliusz Zychowicz (przedm. Krzysztof Mech), Wydawnictwo Znak, Kraków 1994. 
Sarnowski S., Świadomość i czas. O poczatkach filozofii wspótczesnej [Consciousness and Time. On the origins of Modern Philosophy], PWN Scientific Publishers, Warsaw 1985;

Schelling F.W. J., Philosophical Investigations into the Essence of Human Freedom, F.W. J. SCHELLING Translated and with an Introduction by Jeff Love and Johannes Schmidt, State University of New York, 2006;

Tillich P., A Question of the Unconditioned, transl. Juliusz Zychowicz (foreword by Krzysztof Mech), Znak Publishing House, Kraków, 1994. 